Fall 2014

\title{
Transplanting Secured Transactions Law: Trapped in the Civil Code for Emerging Economy Countries
}

Xuan-Thao Nguyen

Bich Thao Nguyen

Follow this and additional works at: https://scholarship.law.unc.edu/ncilj

\section{Recommended Citation}

Xuan-Thao Nguyen \& Bich T. Nguyen, Transplanting Secured Transactions Law: Trapped in the Civil Code for Emerging Economy Countries, 40 N.C. J. INT'L L. 1 (2014).

Available at: https://scholarship.law.unc.edu/ncilj/vol40/iss1/1

This Article is brought to you for free and open access by Carolina Law Scholarship Repository. It has been accepted for inclusion in North Carolina Journal of International Law by an authorized editor of Carolina Law Scholarship Repository. For more information, please contact law_repository@unc.edu. 
Transplanting Secured Transactions Law: Trapped in the Civil Code for Emerging Economy Countries

Cover Page Footnote

International Law; Commercial Law; Law 


\section{Transplanting Secured Transactions Law: Trapped in the Civil Code for Emerging Economy Countries}

Xuan-Thao Nguyen ${ }^{\dagger}$ and Bich Thao Nguyen ${ }^{\dagger t}$

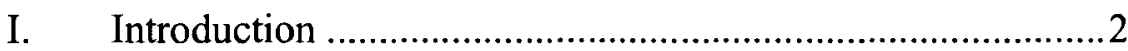

II. An Overview of The International Best Practices in Secured Transactions ....................................................... 7

III. The Desire For A Comprehensive Civil Code In The $21^{\text {st }}$ Century.......................................................................17

IV. The Placement Of Secured Transactions Law Within The Civil Code ...............................................................22

V. The Antiquated Opaque Law.........................................24

A. Antiquated Secured Transactions Law .........................24

B. Opaque, Inconsistent and Contradictory Secured Transactions Law .......................................................29

VI. The Incomplete Law: Missing Property Collateral, Perfection, Priority and Remedies ....................................33

A. Missing Property Collateral ........................................33

B. Missing Perfection Rules ...........................................39

C. Missing Priority Rules ...............................................40

D. Missing Remedies Rules...............................................43

VII. Solutions For Transplanting Secured Transactions

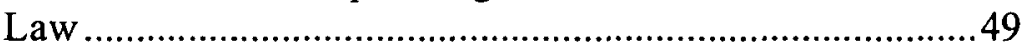

A. Quick Fix with Additional Pain: The Decree Attempts

$\dagger$ Gerald L. Bepko Chair of Law \& Director, Center for Intellectual Property \& Innovation, Indiana University McKinney School of Law; Consultant to World Bank/IFC on the Secured Transactions Project in Mekong Region countries. Many thanks to the participants at seminars on Secured Transactions in the Mekong Region countries. Special thanks to Erik Darwin Hille and Khai-Leif Nguyen-Hille for their love, patience, and support.

†† SJD, SMU Dedman School of Law; Lecturer, Vietnam National University. Special thanks to Professor Xuan-Thao Nguyen for her guidance and support. Many thanks to colleagues at the Ministry of Justice of Vietnam, World Bank/IFC, and the courts in Hanoi and Ho Chi Minh City for enabling the authors to gain access to primary sources in Vietnam. 
B. Different Placement Within the Civil Code?

Moving from "Civil Obligations and Civil

Contracts" to "Property Ownership" Section of the

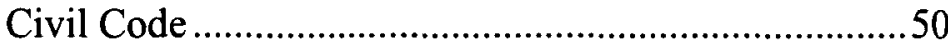

C. A Separate Body of Law Apart from the Civil Code ...52

VIII. Conclusion .54

\section{Introduction}

Despite having a cheap and capable labor force, it costs more to produce a jacket for export in a poor, developing country than it costs to produce the same jacket in China. This revelation surprises many. The lack of access to credit is identified as one of the main reasons for the disparity in production costs. Indeed, the New York Times reported that in 2006, it cost a company in Laos $45 \%$ more than it cost a Chinese company to ship each container of jackets to the United States. ' The "virtually nonexistent credit markets" in Laos caused the high production costs for businesses trying to compete in the global market. ${ }^{3}$ Businesses could not utilize "[their] factory and equipment as collateral for loans in Laos' modest banking market, making it costly and difficult to borrow." As a result, Laotian goods could not compete with those made in China. A neighbor of Laos, Vietnam, faced a similar challenge and decided to transplant secured transactions law in Vietnam in 1995 and again in $2005 .^{5}$

Despite the bragging right of having implemented secured transactions law in Vietnam almost two decades ago, Vietnamese businesses continue to lack access to credit, and the secured

1 See Keith Bradsher, Ending Tariffs Is Only the Start, N.Y. Times, Feb. 28, 2006, available at http://www.nytimes.com/2006/02/28/business/worldbusiness/28laos.html ?n=Top\%2FReference\%2FTimes\%20Topics\%2FSubjects\%2FT\%2FTaxes\&_r $=0$.

2 Id.

3 See id.

4 Id.

5 See Code Civ. [C. Civ.] (1995) (Viet.); Code Civ. [C. Civ.] (Viet.). Cambodia also transplanted secured transactions law, as Vietnam did. See COUNCIL FOR THE DEVELOPMENT OF CAMBODIA, LAW ON SECURED TRANSACTIONS, available at http://www.cambodiainvestment.gov.kh/law-on-secured-transaction_070523.html. See generally Michael Popkin, Secured Transactions, PhNom Penh Post, Sept. 20; 1996, http://www.phnompenhpost.com/national/secured-transactions (discussing Cambodia's old secured transaction law). 
financing market is underdeveloped. ${ }^{6}$ A closer examination of the current secured transactions law in Vietnam reveals that Vietnam did not follow the international best practices when adopting its own secured transactions law. As a result, Vietnam transplanted an antiquated, opaque, and incomplete body of secured transactions law and trapped secured transactions law deep inside a copiously webbed Civil Code.

During the early 2000s, the United Nations Commission on International Trade Law (UNCITRAL) ${ }^{7}$ convened in Vienna and New York City to draft a comprehensive, clear, and concise international guide for secured transactions to encourage credit availability. ${ }^{8}$ Disregarding the international community's efforts, Vietnam charted its own course in designing its secured transactions law. ${ }^{9}$

Vietnam, believing that civil law offers the best approach to creating secured transactions law, adopted the approach, structure, and provisions that international communities had already acknowledged as antiquated. In fact, the international community had already replaced this antiquated system with the UNCITRAL Legislative Guide. Rather than following the international trend, Vietnam consulted experts from other civil law countries and transplanted their antiquated system into its own secured transactions law. Thus, Vietnam's secured transactions laws were

6 Most businesses in Vietnam have been experiencing the long-term problem of lacking credit. See Lack of Credit Hampers SMEs, VIÉT NAM NEWS (Sept. 18, 2010, 9:46 AM), http://vietnamnews.vn/economy/203785/lack-of-credit-hampers-smes.html (reporting that Vietnamese businesses cited the lack of credit as their biggest problem).

7 UNCITRAL was established by the United Nations General Assembly by its Resolution 2205 (XXI) of 17 December 1966 "for the promotion of the progressive harmonization and unification of the law of intemational trade." G.A. Res. 2205 (XXI), U.N. GAOR, 21 st Sess., Supp. No. 16, U.N. Doc. A/6594, at 5 (Dec. 17, 1966). In 2001, UNCITRAL established Working Group VI "with the mandate to develop an efficient legal regime for security rights in goods involved in a commercial activity, including inventory." Sandra M. Rocks \& Kate A. Sawyer, Survey of International Commercial Law Developments During 2002, 58 Bus. LAw. 1657, 1661 (2003). Working Group VI met regularly in New York City and Vienna to develop the Legislative Guide on Secured Transactions completed in 2007. See Sandra M. Rocks \& Kate A. Sawyer, International Commercial Law: 2007 Developments, 63 BuS. LAw. 1375, 1380 (2008).

8 See UNCITRAL, Legislative Guide on Secured Transactions, U.N. Sales No. E.09.V.12 (2007) [hereinafter LEGISLATIVE GUIDE].

9 Vietnam is not a member of UNCITRAL. See UNCITRAL, Origin, Mandate, and Composition of UNCITRAL (2014), http://www.uncitral.org/uncitral/en/about lorigin.html. 
outdated before they were even enacted. ${ }^{10}$

As a result, Vietnam's secured transactions law cannot keep pace with the ever-changing daily practices related to secured transactions. As individuals and businesses turn to movable assets for financing due to the shrinkage of the credit market based on real estate or immovable property, Vietnam's secured transactions laws fail to facilitate the availability of credit through secured financing." For example, one debtor owed over \$28 million to several lenders, and each lender received a security interest in the debtor's coffee inventory stored in the same warehouse. ${ }^{12}$ One lender went separately to court for a judgment to seize some of the inventory, while other lenders vigorously opposed. ${ }^{13}$ All lenders sent in troops, trucks, and guards to encircle the warehouse, ${ }^{14}$ where fighting and violence ensued. Police officers were deployed to maintain order. ${ }^{15}$ In the end, when access to the coffee inventory was allowed, it was discovered that the existing inventory was only half the amount reported by the debtor. ${ }^{16}$

This Article argues that Vietnam cannot and will not be able to promptly address similar problems and market concerns in secured financing because its secured transactions law is structurally confined inside Vietnam's Civil Code. The Civil Code, Vietnam's proud achievement, is a massive body of law that covers all "civil" transactions and matters. The vast scope of the Civil Code includes property law, torts law, contract law, family law, employment law, wills and trust law, and secured transactions law,

10 See infra Parts III, IV.

11 See infra Part IV.

12 See Coffee Firm Leaves Banks with Bags of Bitter Debt, VIETNAMNET (Dec. 20, 2013), http://english.vietnamnet.vn/fms/business/91785/coffee-firm-leaves-banks-withbags-of-bitter-debt.html.

13 Id.

14 Id.

15 See 7 Banks Attempt to Seize Goods from Debtor (July 6, 2013), TUOITRENEWS.vN, http://tuoitrenews.vn/society/10424/7-banks-attempt-to-seize-goodsfrom-debtor.

16 See Le Chi \& Thanh Lan, Hanh Trinh No Nan Cua Dai Gia Ca Phe Tai 7 Nha Bang [How Did a Coffee Giant Become Severely Indebted to Seven Banks], VNEXPRESS (Dec. 12, 2013), http://kinhdoanh.vnexpress.net/tin-tuc/ebank/ngan-hang/hanh-trinh-nonan-cua-dai-gia-ca-phe-tai-7-nha-bang-2921595.html. Of the 1,500 tons of inventory, only 700 tons were comprised of coffee; the rest was garbage disguised as coffee. Id. 
all under one roof. ${ }^{17}$ As a result, the Civil Code is incomprehensible on a practical level.

Since secured transactions are viewed as "civil," secured transactions law is embedded inside Vietnam's Civil Code. Thus, Vietnam cannot amend secured transactions law without amending the entire Civil Code. Amending the Civil Code is a task that Vietnam is not willing to undertake frequently. Moreover, Vietnam cannot routinely amend the Civil Code for secured transactions law alone.

Additionally, the placement of secured transactions law under the "Civil Obligations" part of the Civil Code fails to grasp that secured transactions include not only recognizing different and new types of property rights and interests, but also allowing property rights and interests to be utilized as collateral in order to increase credit availability. ${ }^{18}$ Secured transactions are not merely "obligations." Situating secured transactions law under "Civil Obligations" led to the creation of an incomplete body of law that lacked fundamental rules relating to perfection, priority, and remedies of secured transactions. Overall, the secured transactions law is antiquated, opaque, and incomplete. ${ }^{19}$ Consequently, individuals and businesses in Vietnam are desperate for credit while lenders have no incentive to engage in meaningful and enforceable financing.

It is time for Vietnam to amend its secured transactions law by creating a body of secured transactions law separate from the Civil Code. This new secured transactions law should embody the international community's unitary approach. Separating secured transactions law from the Civil Code would allow Vietnam to revise its secured transactions law to respond and adapt to market reality, without waiting for the entire Civil Code to be revised all at once.

This Article will proceed as follows. Part I provides an overview of the international best practices in secured transactions, discussing UNCITRAL's Legislative Guide and Article 9 of the Uniform Commercial Code. Part II explores why and how

17 See generally CODE CIV. [C. CIV.] (Viet.) (encompassing property law, torts law, contract law, family law, employment law, wills and trust law, and secured transactions law).

18 See infra Part II.

19 See infra Part IV. 
Vietnam adopted a massive and incomprehensible Civil Code in the twenty-first century. Part III discusses the placement of secured transactions law inside the Civil Code and the problems associated with such placement. Part IV analyzes and critiques Vietnam's secured transactions law as antiquated and opaque. Part $\mathrm{V}$ demonstrates the fundamental rules currently missing in Vietnam's secured transactions law and how Vietnamese businesses are suffering as a result of this incomplete body of secured transactions law. Part VI considers a number of solutions, from using government decrees to circumvent the existing law to moving the secured transactions law from the "Civil Obligations" part to the "Property Ownership" part of the Civil Code. Part VI also analyzes and discusses potential problems associated with these solutions. Ultimately, Part VI concludes that the best solution would be for Vietnam to create a body of secured transactions law distinct from the Civil Code.

Vietnam's experience of transplanting secured transactions law is not unique and is illustrative of "civil law" emerging economy countries. This Article concludes that transplanting law, specifically commercial and financing law, requires emerging economies, including Vietnam, to reevaluate the belief that the "civil law" countries' approach is the best, particularly since this approach has already been proven to be antiquated, opaque, and incomplete by the international community. ${ }^{20}$

20 Numerous writings have discussed different legal transplant theories; therefore, it is unnecessary for this Article to reiterate these theories. For an overview of legal transplant literature, see JoHn STANLEY GiLlespie, Transplanting CoMmercial LaW REFoRm: Developing A Rule OF LAW IN VIETNAM 18-26 (2006) (outlining four major theories to legal transplants: (1) legal evolution; (2) limited legal autonomy; (3) legal autonomy; and (4) systems theory). The legal evolution theory, proposed by Sir Henry Main and Max Weber, asserts that less developed legal systems will evolve to emulate more developed legal systems. See id. at 18-19. The limited legal autonomy theory, developed by Montesquieu, Pierre Legrand, and Otto Kahn-Freund, argues that law is socially and culturally embedded and thus can only be somewhat transferred from one country to another, depending on the extent of relationship between the transplanted rule with its original country, or it may not be transferable at all. See id. at 20-22. Alan Watson, the architect of the extreme legal autonomy theory, maintains that law is transferrable "freely across cultural barriers." Id. at 23 . The systems theory, devised by Gunther Teubner and Niklas Luhmann, "provides a point of departure from the previously discussed state-centered theories," and avers that "people within institutions such as companies, political bodies or universities create their own kind of reality and meanings." Id. at 24. However, none of the above general theories provides a satisfactory analytical framework to evaluate the viability of legal transplant. This 


\section{An Overview of The International Best Practices in Secured Transactions}

The UNCITRAL Legislative Guide on Secured Transactions ("Legislative Guide"), which was adopted in $2007^{21}$ and modeled after Article 9 of the Uniform Commercial Code ("UCC"), represents the international best practices and epitomizes a modern secured transactions regime. ${ }^{23}$ Although secured transactions captured the attention of UNCITRAL and other international

Article thereby identifies the current problem of transplanting secured transaction law in Vietnam and proposes solutions in response to the concerns of stakeholders affected by such law.

21 See Legislative Guide, supra note 8.

22 See Spyridon V. Bazinas, Senior Legal Officer, UNCITRAL Secretariat, The Influence of the UNCITRAL Legislative Guide, 4 (Nov. 5, 2013), available at http://www.ebrd.com/downloads/legal/secured/bazinas l t.pdf.

23 Obviously, the Legislative Guide and Article 9 of the UCC are not flawless, but they codify best practices in the financing industry and make significant contributions to the reforms of secured transactions laws worldwide and the improvement of access to credit. This Article does not purport to analyze the shortcomings of the Legislative Guide and Article 9. For critiques of Article 9, see, e.g., Robert K. Rasmussen, The Uneasy Case Against the Uniform Commercial Code, 62 LA. L. Rev. 1097, 1100-01 (2002) (summarizing the scholarship attacking Article 9, including the assertion that "Article 9 encouraged inefficient investment," and that contractual priority can generate benefit for society without Article 9); Steven L. Harris \& Charles W. Mooney, Jr., Using First Principles of UCC Article 9 to Solve Statutory Puzzles in Receivables Financing, 46 GONZ. L. REV. 297, 298 (2011) (identifying the problem that the relationship between Article 9 and related non-UCC law is unclear); Thomas E. Plank, Assignment of Receivables Under Article 9: Structural Incoherence and Wasteful Filing, 68 Оню ST. L.J. 231, 231 (2007) (arguing that "Article 9's treatment of the assignment of receivables has produced a variety of calamities for both the drafters and the users of Article 9."); Paul M. Shupack, The Assignee of an Article 9 Security Interest: Two Sets of Drafting Errors and How to Live with Them, 46 GoNz. L. REv. 503, 504 (2011) (noting that "[c]ertain provisions of Article 9 fail to produce sensible results" with respect to assignment of security interests); Xuan-Thao Nguyen, Collateralizing Intellectual Property, 42 GA. L. REv. 1, 32-37 (2007) (criticizing Article 9's overly broad definition of "general intangibles," which fails to provide notice to secured party and the debtor that intellectual property is encumbered). For critiques of the Legislative Guide, see, e.g., John J. Chung, A Fundamental Flaw with UNCITRAL's Approach to Cross-Border Secured Transactions: The Failure to Address Creditor Due Diligence Issues, 20 Ам. BANKR. INST. L. REV. 557, 563 (2012) (contending that "the Legislative Guide is a pale imitation, at best, of Article 9, and cannot achieve what Article 9 has achieved," and questioning "whether the Legislative Guide is necessary at all"); Haider Ala Hamoudi, The American Commercial Religion, 10 DePaul Bus. \& CoM. L.J. 107, 148 (2012) (observing limitations of the Legislative Guide compared to a model law, such as its failure to "prevent the law from creating preferences over secured creditors as to secured property"). 
institutions back in the late $1970 \mathrm{~s},{ }^{24}$ UNCITRAL did not resume its work on devising an international legal framework for secured transactions until $2001 .^{25}$ The global problem of obtaining credit due to deficient domestic secured transactions laws prompted UNCITRAL to restart this grand project. ${ }^{26}$ Moreover, with the arrival of the Internet in the late 1990s, the world witnessed the emergence of new kinds of property that could serve as collateral. In 2001, the international community decided that the time was ripe to develop a comprehensive set of legal standards for secured transactions in the form of a legislative guide to assist legislatures worldwide "in developing modern secured transactions laws," "with a view to promoting the availability of credit."

The primary goal of modern secured transactions law is to promote low-cost credit by amplifying the availability of credit and allowing businesses and individuals to utilize the full value of their assets to obtain financing. ${ }^{28}$ To achieve this goal, modern secured transactions law rejects the antiquated approach that distinguishes among security devices and adopts the unitary approach to secured transactions. This unitary approach recognizes that all transactions that create a security interest in any type of asset to secure an obligation are considered secured transactions, regardless of the name or form of the transaction, the type of collateral, the status of the debtor or secured party, or the

24 See UNCITRAL Security Interests: Current Activities and Possible Future Work: Rep. of the Secretary-General, U.N. Doc. A/CN.9/475 (Apr. 27, 2000) (outlining the previous initiatives of various international institutions to harmonize secured transactions law) [hereinafter UNCITRAL Security Interests]; Rep. of the United Nations Commission on International Trade Law on its Thirty-Fourth Session, June 25July 13 2001, If 346, U.N. Doc. A/56/17, 56th Sess., Supp. No. 17 (2001) (noting that UNCITRAL's interest and work on security interests dated back to the late 1970s); see also Spiros V. Bazinas, UNCITRAL's Work in the Field of Secured Transactions, 36 No. 4 UCC L. J. ART 2 (2004).

25 See Rocks \& Sawyer, Survey of International Commercial Law Developments During 2002, supra note 7.

26 See UNCITRAL Security Interests, supra note $24, \uparrow 41$, | 63, at 15 (identifying that despite international and national efforts to improve secured transactions legal framework, "domestic legal systems governing secured credit are simply inadequate to support the extension of credit at lower costs," thus "imped[ing] international commerce" and "creating a competitive disadvantage for business parties who do not have sufficient access to lower-cost credit").

27 LegisLative Guide, supra note 8 , $\{\mathrm{I}$, at 1.

28 See LegiSLATIVE GuIDE, supra note 8, 149-50, at 20. 
nature of the secured obligation. ${ }^{29}$ Under the unitary approach, secured transactions law encompasses not only traditional security devices such as pledges and mortgages, but also transactions that are typically not denominated as secured transactions but nevertheless serve security purposes. ${ }^{30}$ These transactions include sales with retention of title, ${ }^{31}$ financial leases, ${ }^{32}$ consignments, ${ }^{33}$ and sales of accounts. ${ }^{34}$ The unitary approach "ensures comprehensiveness, consistency, and transparency" 35 of secured transactions law, "promotes competition among credit providers by placing sellers, lessors, and lenders on a level playing field," 36 and reduces creditors' burden in investigating the different requirements of various security devices, thus lowering transaction costs overall. ${ }^{37}$

With regard to property collateral, modern secured transactions law allows all kinds of personal property to be utilized as collateral: from tangible to intangible property, existing to afteracquired property, and original collateral to proceeds of collateral. $^{38}$ Tangible property typically covers consumer goods,

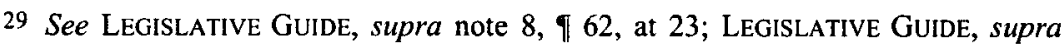
note 8, Recommendation 2, at 61; U.C.C. § 9-109(a) (2010) (setting forth the scope of Article 9).

30 See LegiSLATIVE GuIDE, supra note 8 , Recommendation 8 , at 62 ; U.C.C. $\S 9$ 109(a) (2010).

31 A sale with retention of title occurs when the seller sells goods on credit and the parties agree that ownership of the goods is not transferred from the seller to the buyer until payment is made in full. See LegisLATIVE GUIDE, supra note 8, Introduction, at 12.

32 A financial lease is a lease agreement under which, at the end of the lease, the lessee automatically becomes the owner of the leased property and may acquire ownership by paying a nominal price, or the leased property has "no more than a nominal residual value." See LEGISLATIVE GUIDE, supra note 8, Introduction, at 9; see also U.C.C. $\S 1-203$ (b) (2001) (setting forth factors to determine whether a lease creates a security interest).

33 A consignment covered by secured transactions law is a transaction in which a person delivers goods for the purpose of sale to a merchant dealing in goods of that kind and the merchant "is not generally known by its creditors to be substantially engaged in selling the goods of others." U.C.C. § 9-102(20) (2010).

34 See Legislative Guide, supra note 8 , If 25 , at 37 (explaining that outright transfers of receivables are included in the scope of secured transactions); see also U.C.C. § 9-109(a) (2010) (the scope of Article 9 includes sales of accounts).

35 Legislative Guide, supra note 8 , $\uparrow 105$, at 56.

36 Id.

37 See LegiSlative Guide, supra note 8, 161 , at 23.

38 See LegiSlative Guide, supra note 8, Recommendation 2(a), at 61; see also 
inventory, and equipment. ${ }^{39}$ Tangible property also includes fixtures, which are "goods that have become so related to particular real property that an interest in them arises under real property law." ${ }^{40}$ Quasi-tangible property, including instruments (such as checks, promissory notes, or bills of exchange), ${ }^{41}$ documents of title (such as bills of lading or warehouse receipts), ${ }^{42}$ chattel paper, ${ }^{43}$ and investment property (securities), ${ }^{44}$ can also serve as collateral. Intangible property encompasses a wide variety of rights and interests, such as contractual and noncontractual receivables, contractual non-monetary claims, deposit accounts, ${ }^{45}$ letter-of-credit rights, ${ }^{46}$ commercial tort claims, ${ }^{47}$ intellectual property, ${ }^{48}$ and other types of intangibles. Modern secured transactions law has recognized the rising importance of

U.C.C. § 9-102(12) (2010) (defining "collateral").

39 See Legislative Guide, supra note 8, Introduction, at 13 (defining "tangible asset"). Article 9 of the UCC also includes "farm products" as a subset of tangible assets (goods). See U.C.C. § 9-102(34) (2010).

40 U.C.C. \$ 9-102(41) (2010). The Legislative Guide uses the term "attachment to immovable property" to denote fixtures. See LeGISLATIVE GuIDE, supra note 8, Introduction, at 7 ('“Attachment to immovable property' means a tangible asset that is so physically attached to immovable property that, despite the fact that it has not lost its separate identity, it is treated as immovable property ....").

41 See Legislative Guide, supra note 8, Introduction, at 11 (defining "negotiable instrument"); see also U.C.C. § 9-102(47) (2010) (defining “instrument").

42 See Legislative Guide, supra note 8, Introduction, at 10 (defining "negotiable document"); see also U.C.C. § 1-201(16) (2001) (defining "document of title").

43 See U.C.C. $\$ 9-102(11)$ (2010) (defining "chattel paper" as "a record or records that evidence both a monetary obligation and a security interest").

44 See U.C.C. \& 9-102(49) (2010) (defining "investment property"). The UNCITRAL Legislative Guide does not apply to security interests in securities but nevertheless acknowledges the importance of securities as collateral that "merit special legislative treatment." See LegisLATIVE Guide, supra note 8, \37, at 40.

45 See Legislative Guide, supra note 8, Recommendation 2(a), at 61 (including "rights to payment of funds credited to a bank account" as collateral); see also U.C.C. $\S$ 9-102(29) (defining "deposit account").

46 See LeGiSLative Guide, supra note 8, Recommendation 2(a), at 61 (explaining that collateral includes "rights to receive the proceeds under an independent undertaking”); See LeGiSLATIVE Guide, supra note 8, Introduction, at 9 (defining "independent undertaking" as a letter of credit, a confirmation of a letter of credit, or an independent guarantee); see also U.C.C. \$ 9-102(51) (defining "letter-of-credit right" as a right to payment or performance under a letter of credit).

47 See U.C.C. \& 9-102(13) (2010) (defining "commercial tort claim").

48 See Legislative Guide, supra note 8, Recommendation 2(a), at 61. 
intangible assets in secured financing in recent years ${ }^{49}$ and provides specific rules accommodating these new assets.

Modern secured transactions law also emphasizes the significance of proceeds as collateral. By recognizing proceeds, the law allows the secured party to maintain its security interest and priority regardless of whether the original collateral is in the hands of the debtor or has been transferred to other third parties. ${ }^{50}$ Additionally, commercial transactions are facilitated because the collateral is allowed to flow freely in the stream of commerce. In modern secured transactions law, the term "proceeds" has a very broad meaning. 51

By permitting a vast range of property to be used as collateral, modern secured transactions law enables debtors to maximize the value of both traditional and newly recognized property, rights, and interests to obtain credit. To further facilitate secured financing, modern secured transactions law recommends minimal requirements for the creation and attachment of security interests. For a security interest to "attach" to the collateral (to be effective against the debtor), the UNCITRAL Legislative Guide recommends that a security agreement between the debtor and the secured party be executed with a description of the collateral that reasonably identifies the collateral and that the debtor has rights in the collateral or the power to transfer rights in the collateral. ${ }^{52}$ The security agreement can be in writing, or it can be oral if accompanied by the secured party's possession of the collateral. ${ }^{53}$

49 See Legislative Guide, supra note 8, I 78, at 49 ("In view of the dramatic increase in the economic importance of intangible assets in recent years, there is a growing demand to use these rights as security for credit.").

50 See Legislative Guide, supra note $8, \uparrow 74$, at 84 (discussing the rationale for recognizing security interests in proceeds).

51 Proceeds constitute "whatever is received in respect of encumbered assets, including what is received as a result of sale or other disposition or collection, lease or license of an encumbered asset, proceeds of proceeds, natural and civil fruits or revenues, dividends, distribution, insurance proceeds and claims arising from the defects in, damage to or loss of an encumbered asset." LEGISLATIVE GUIDE, supra note 8, Introduction, at 11-12; see also U.C.C. § 9-102(64) (2010).

52 See Legislative GuIdE, supra note 8, Recommendations 13-14, at 97-98; see also U.C.C. $\$$ 9-203(b) (2010) (listing the U.C.C. requirements regarding the enforceability of security interests).

53 LEgisLATIVE GuIDE, supra note 8 , Recommendation 15 , at 98 ; see also U.C.C. $\$$ 9-203(b)(3)(A)-(B) (2010) (containing the U.C.C. writing requirement for secured transactions). 
It is important that the requirements for attachment of a security interest be distinct from the requirements for perfection of the security interest. ${ }^{54}$ Perfection requires attachment plus an additional act such as filing, taking possession, or taking control of the collateral. ${ }^{55}$ This distinction encourages the creation of security interests because it respects the parties' autonomy and freedom of contract. ${ }^{56}$ With a security agreement satisfying the attachment requirements, the security interest can be enforced against the debtor without further formalities. ${ }^{57}$ Another notable feature of modern secured transactions law is that the debtor is not required to own the collateral and is only required to have rights in the collateral or the power to transfer rights in the collateral. ${ }^{58} \mathrm{~A}$ debtor's "limited rights in collateral, short of full ownership, are sufficient for a security interest to attach." 59

Regarding perfection of a security interest, modern secured transactions law provides different methods of perfection that take into account the financing practice in each industry and the specific features of new kinds of intangible property, including: perfection by taking possession, perfection by filing (registration), perfection by control, automatic perfection upon attachment, and perfection by notation on certificate of title. ${ }^{60}$ The purpose of perfection is to put all third parties on notice and assist them in making an informed decision before advancing credit or engaging in other transactions involving the collateral. ${ }^{61}$ Moreover, perfection serves as the basis to determine priority between a security interest and a competing interest. ${ }^{62}$ Therefore, perfection enhances the transparency and predictability of secured

54 LegiSLATIVE GuIDE, supra note 8, ๆf 6-7, at 104; see also U.C.C. $\$ 9-308 \mathrm{cmt} .2$ (2010) ("Perfection" refers to the point at which the secured party is protected against third parties, such as creditors and transferees of the debtor.).

55 LegiSLATIVE GuidE, supra note 8, I 3, at 65; see also U.C.C. § 9-308(a) (2010) (explaining when a security interest is perfected).

56 See LegislaAtive Guide, supra note 8 , $\uparrow 3$, at 65 .

57 Legislative Guide, supra note $8, \uparrow 3$, at 65 .

58 See U.C.C. $\$ 9-203(\mathrm{~b})(2)$ (2010).

59 Id. $\S 9-203 \mathrm{cmt} .6$.

60 See LegiSLATIVE GuidE, supra note 8, Recommendations 32, 34, at 143-44; see also U.C.C. $\$ \S 9-309-9-315$ (2010) (detailing the U.C.C. requirements and guidelines for perfection).
61 See LegisLative Guide, supra note 8, 1 1, at 103.
62 See id. 
transactions. ${ }^{63}$ Although filing is the most common way to perfect a security interest, it is not the only way, and in some cases, not the optimal way for certain kinds of collateral. For example, the secured party can directly take possession of tangible collateral as a way to give notice to the outside world of its security interest and to assert priority, or possession can be achieved by having a third party hold the collateral for the benefit of the secured party with proper authentication. ${ }^{64}$ For intangible property that does not exist in a physical form, such as account receivables and intellectual property, filing is the only way to perfect the security interest. For certain kinds of collateral such as securities, deposit accounts, or letter-of-credit rights, control is the optimal way to perfect the security interest according to industry practices. ${ }^{65}$ Also, in some instances, perfection can occur automatically upon attachment without any additional steps, such as perfection of a security interest in proceeds ${ }^{66}$ or perfection of a purchase-money security interest in consumer goods. ${ }^{67}$

Elaborate rules for property collateral and perfection set the stage for a clear, transparent, and comprehensive set of priority

63 See id.

64 See LegisLative GUIDE, supra note 8, Recommendation 37, at 144 (explaining that "a security right in a tangible asset may be made effective against third parties by registration" or "by the secured creditor's possession"); see LEGISLATIVE GUIDE, supra note 8, Introduction, at 11 (defining the term "possession" as including actual possession "by a person or an agent or employee of that person, or by an independent person that acknowledges holding [the collateral] for that person"); see also U.C.C. $\$ 9-313$ (2010) (detailing "when possession by or delivery to a secured party perfects security interest without filing").

65 See Legislative Guide, supra note 8, Introduction, at 8 (defining "control"); see also LEGISLATIVE GUIDE supra note 8, Recommendations 49-50, at 146-47 (recommending "obtaining control" for "third-party effectiveness of a security right"); U.C.C. § 9-314 (2010) (detailing "perfection by control").

66 See LegiSLATIVE GuIDE, supra note 8, Recommendation 39, at 145 (explaining an automatic perfection of a security interest in proceeds).

67 See LegiSLATIVE Guide, supra note 8, Recommendation 179, at 375 (automatic perfection of a purchase-money security interest in consumer goods); U.C.C. $\$$ 9-309 (2010) (detailing when a security interest perfected upon attachment); see also LEGISLATIVE GUIDE, supra note 8, Introduction, at 6 (The Legislative Guide uses the term "acquisition security right" instead of "purchase-money security interest" with an "acquisition security right" being "a security right in a tangible asset ... that secures the obligation to pay any unpaid portion of the purchase price of the asset or an obligation incurred or credit otherwise provided to enable the grantor to acquire the asset"); LEGISLATIVE GUIDE supra note 8, \57, at 332 (explaining the substitution of "acquisition security right" for "purchase-money security interest"). 
rules, which are imperative to enhance the availability of secured credit because they ensure predictability for a secured party. ${ }^{68}$ Modern secured transactions law takes into account every potential competing interest in all sorts of collateral and all types of secured transactions. Apart from the basic "first in time to file or perfect" rule,$^{69}$ the law contemplates various scenarios of priority conflicts between the secured party and a lien creditor (such as a judgment lien creditor, a tax lienholder, or a bankruptcy trustee) ${ }^{70}$ between the secured party and a purchase-money secured party, ${ }^{71}$ between the secured party and different kinds of buyers, transferees, lessees, and licensees of the collateral, ${ }^{72}$ between the secured party and the persons providing services with respect to the collateral, etc. ${ }^{73}$ Furthermore, modern secured transactions law designs assetspecific priority rules for after-acquired property, fixtures, negotiable instruments, negotiable documents, deposit accounts, letter-of-credit rights, and so forth. ${ }^{74}$

The two fundamental concepts in the context of determining priority, "purchase-money security interest" and "buyer in ordinary course of business," are well-developed in modern secured transactions law as exceptions to the general "first to file or perfect" rule. ${ }^{75}$ A purchase-money security interest ("PMSI") is

68 See LegiSLATIVE Guide, supra note 8, $\uparrow 18$, at 189.

69 See LegisLative Guide supra note 8, Recommendation 76, at 230; see also U.C.C. $\$ 9-322(a)$ (2010) (providing that the first party to file or to perfect the security interest will have priority, and a perfected security interest has priority over a conflicting unperfected security interest; if both conflicting security interests are unperfected, the first security interest to attach or become effective will have priority).

70 See LegiSLATIVE GUIDE, supra note 8, Recommendations 83-84, at 231; see also U.C.C. $\S 9-317$ (a) (2010) (describing which interests take priority when there is a conflict).

71 See LEGISLATIVE GuIDE, supra note 8, Recommendations 178-86, at 374-77; see also U.C.C. $\S 9-324$ (2010) (detailing the rules for priority of purchase-money security interests).

72 See LegisLative Guide, supra note 8, Recommendation 79, at 230-31; see also U.C.C. $\S \S 9-317(b), 9-317$ (e), 9-320, 9-331 (2010) (describing the provisions for which interests take priority).

73 LegisLATIVE GUIDE, supra note 8, Recommendation 85, at 232; see also U.C.C. $\S 9-333$ (2010) (describing the priority of certain kinds of liens).

74 See Legislative GuidE, supra note 8, Recommendations 87-89, 101-09, at 23235; see also U.C.C. $\$ \S 9-327-9-334$ (2010) (containing the U.C.C. provisions for priority of specific assets).

75 See U.C.C. $\S 9-103$ (b) (2010) (defining "purchase-money security interest in goods"); see also U.C.C. $§ 1-201(9)$ (2011) (defining "buyer in ordinary course of 
created where the secured party extends credit to enable the debtor to purchase the collateral or acquire rights in the collateral. ${ }^{76}$ Modern secured transactions law gives priority to a secured party who has a purchase-money security interest, even if the PMSI comes later than a pre-existing perfected security interest ${ }^{77}$ in order to encourage financing for the acquisition of property, which stimulates consumption, production, and commerce, and increases the ability of the debtor to pay off the debts owed to other creditors. ${ }^{78}$

Modern secured transactions law also favors a buyer in the ordinary course of business ${ }^{79}$ by allowing such buyer to take free of a security interest created by the buyer's seller, even if the security interest is perfected and the buyer knows of its existence. ${ }^{80}$ This rule is crucial to ensure the free flow of goods in commerce; meanwhile, the secured party is still protected because its security interest automatically attaches to the proceeds generated when the collateral is sold. ${ }^{81}$

With respect to remedies, modern secured transactions law highly encourages secured financing by providing a comprehensive set of rules allowing a secured party to efficiently enforce its security interest without abusing its rights. ${ }^{82}$ The law recognizes that a secured party has cumulative rights upon default, meaning that when the debtor defaults, the secured party may

business").

76 See LegISLATIVE Guide, supra note 8, Introduction, at 6 (defining "acquisition security right"); see also U.C.C. \$ 9-103(b) (2010) (defining "purchase-money security interest in goods").

77 See LegISLATIVE Guide, supra note 8, Recommendations 179-80, at 375-76; see also U.C.C. $\$ 9-324$ (2010) (detailing the priority of purchase-money security interests)

78 See Legislative Guide, supra note 8, If 4, at 319 ("Acquisition financing transactions are not only among the most important sources of credit for many buyers of tangible assets, but they are also critical to many sellers.").

79 See U.C.C. § 1-201(9) (2011) (A buyer in the ordinary course of business is "a person that buys goods in good faith, without knowledge that the sale violates the rights of another person in the goods, and in the ordinary course from a person, other than a pawnbroker, in the business of selling goods of that kind.").

80 See LegiSLATIVE GuidE, supra note 8, Recommendation 81, at 231; see also U.C.C. $\$ 9-320$ (a) (2010) (describing how a buyer in the ordinary course of business takes free of a security interest even if it is perfected and the buyer has knowledge of it).

81 See U.C.C. $\$ \S 9-203(f), 9-315(a)(2)$ (2010) (detailing that "a security interest attaches to any identifiable proceeds of collateral.").

82 See LegisLative Guide, supra note 8, \6, at 276. 
reduce a claim to judgment, foreclose on the collateral, or otherwise enforce the claim or security interest by any available judicial procedure. ${ }^{83}$ Upon default, the secured party can take possession of the collateral by judicial process or by exercising self-help (extra-judicial repossession) "without breach of the peace." 84 The law gives a secured party a wide range of discretion in disposition of the collateral, but requires the secured party to comply with certain requirements such as providing notice of disposition ${ }^{85}$ following the "commercially reasonable" standard, ${ }^{86}$ and distributing the proceeds in certain order. ${ }^{87}$ Instead of disposition, the secured party can exercise "strict foreclosure" by accepting the collateral in full or partial satisfaction of the obligation. ${ }^{88}$ Strict foreclosure is a less expensive and quicker way to enforce a security interest. ${ }^{89}$ To prevent abuses, the law sets forth specific requirements that the secured party must follow when exercising strict foreclosure. ${ }^{90}$ Moreover, the debtor can

83 See LegiSlative Guide, supra note 8 , 7 34, at 284-85; see also LEGISLATIVE GUIDE, supra note 8, Recommendation 143, at 312 (explaining cumulative post-default rights); U.C.C. $\S 9-601(a),(c)$ (2010) (explaining the "rights of a secured party after default").

84 U.C.C. § 9-609 (2010); see also id. at cmt. 3 (2010) (explaining that what constitutes as "without breach of the peace" is assessed on a case-by-case basis).

85 See LeGiSLATIVE Guide, supra note 8, Recommendations 149-51, at 313-14; see also U.C.C. $\$ 9-612$ (2010) (containing the requirements for notice before disposition of collateral).

86 See Legislative GUIDE, supra note 8, Recommendation 131, at 310 (introducing the commercially reasonable standard); see also LEGISLATIVE GuIDE, supra note 8, Recommendation 148 , at 313 (stipulating that a secured party is subject to the "commercially reasonable" standard as to the "method, manner, time, place and other aspects of the disposition"); U.C.C. $§ 9-610$ (a)-(b) (2010) (stipulating that a secured party seeking a deficiency judgment after the disposition of collateral must prove that the disposition of the collateral is "commercially reasonable," which is measured by method, manner, time, place, and other terms of the disposition).

87 See Legislative GuidE, supra note 8, Recommendations 152-55, at 314; see also U.C.C. \$ 9-615(a) (stating the proceeds of disposition are applied in the following order to: (1) the reasonable expenses of disposition incurred by the secured party; (2) the satisfaction of the debt secured by the security interest; (3) the satisfaction of debts secured by any subordinate security interest or other subordinate lien on the collateral; and (4) the debtor, if there is any surplus).

88 See LegiSLATIVE GUIDE, supra note 8, Recommendation 156, at 315; see also U.C.C. $\$ 9-620(2010)$ (explaining "acceptance of collateral in full or partial satisfaction of the obligation").

89 See LegisLATIVE GuIDE, supra note 8, \67, at 296.

90 See LegisLative Guide, supra note 8, Recommendations 157-59, at 315; see 
redeem the collateral before the secured party has disposed of the collateral or entered into a contract for disposition or has exercised strict foreclosure, provided that the debtor tenders the fulfillment of all obligations secured by the collateral and the reasonable expenses and attorney's fees incurred by the secured party for repossessing, holding, preparing for disposition, processing and disposing of the collateral. ${ }^{91}$ The law also provides remedies for the debtor if the secured party violates any rules governing repossession, foreclosure, and disposition. ${ }^{92}$

Modern secured transactions law, as recommended by the UNCITRAL and outlined above, is designed for all countries to adopt, regardless of whether they are "civil law" or "common law" countries. ${ }^{93}$

\section{The Desire For A Comprehensive Civil Code In The $21^{\text {st }}$ Century}

As other civil law countries have done, ${ }^{94}$ Vietnam celebrated the creation of the Civil Code as "central pieces of legislation"95 in Vietnam's legal reform. It was fashioned in connection with the national efforts of moving the country towards a market-based economy. ${ }^{96}$ The Civil Code is Vietnam's proud achievement of

also U.C.C. $\$ 9-620(2010)$ (stipulating that in order to exercise strict foreclosure, the secured party must send a written proposal to the debtor, other secured parties, and any persons with rights in the collateral; the debtor must consent to the proposal in writing within certain number of days after the proposal is sent, or the secured party does not receive a written objection from the debtor or any person entitled to receive the proposal).

91 See U.C.C. § 9-623 (2010).

92 See LEGISLATIVE GUIDE, supra note 8, Recommendations 136-37, at 311; see also U.C.C. § 9-625 (2010) (providing remedies for secured party's failure to comply with the article).

93 See Legislative Guide, supra note 8, $\{3$, at 1 ("The Guide seeks to rise above differences among legal regimes to offer pragmatic and proven solutions that can be accepted and implemented in States with divergent legal traditions (civil law, common law, as well as Chinese, Islamic and other legal traditions).").

94 See Stephen J. Toope, Legal and Judicial Reform through Development Assistance: Some Lessons, 48 MCGILL L.J. 357, 414 (2003) (noting that Vietnam has adopted an entirely new Civil Code, "modelled in part on the relatively new codes of Quebec and the Netherlands").

95 Duc V. Trang, The Practice of Law and Foreign Investment in Vietnam, 22 WHITTIER L. REV. 1067, 1082 (2001).

96 See id. at 1082. 
having one specific body of law that covers all "civil" matters. The first Civil Code took thirteen years to complete and was promulgated in $1995 .{ }^{97}$ In 2005 , the entire Civil Code was revised. ${ }^{98}$

Vietnam, a small country comprising the area of New Mexico ${ }^{99}$ and the fifteenth most populous nation in the world, ${ }^{100}$ looked to ancient Roman law for guidance in creating its Civil Code. ${ }^{101}$ It is perhaps unsurprising that Vietnam paid deference to Roman law, as today's Vietnamese law students, lawyers, judges, and government officials all learn to appreciate the Corpus Juris Civilis, ${ }^{102}$ Rome's famous ancient civil code. The Corpus Juris Civilis $^{103}$ is a codification of Roman law in 529-534 AD that later formed the foundation of civil law legal systems, including the Napoleonic Code. ${ }^{104}$ Though Vietnam's legal system is new, as

97 See id. ("The Civil Code is the result of thirteen years of work and is the first code to be promulgated by Vietnam since Ho Chi Minh declared the country's independence in September 1945.").

98 See C. Civ. (Viet.).

99 See The World Factbook: Vietnam, CENT. INTELLIGENCE AGENCY, https://www.cia.gov/library/publications/the-world-factbook/geos/vm.html (last visited Aug. 24, 2014) (listing Vietnam's area as 127,880 square miles or 331,210 square kilometers); State \& County QuickFacts: New Mexico, UNITED STATEs Census BUREAU, http://quickfacts.census.gov/qfd/states/35000.html (last visited Aug. 24, 2014) (listing New Mexico's area as 121,298 square miles or 314,160 square kilometers).

100 See The World Factbook: Vietnam, Cent. InTELligence AgENCY, https://www.cia.gov/library/publications/the-world-factbook/geos/vm.html (last visited Aug. 24, 2014) (listing Vietnam's population as 15 th in the world).

101 See the famous ancient civil code, the Corpus Juris Civilis, a codification of Roman law in 529-534 AD by the Byzantine emperor Justinian I, which later formed the basis of civil law legal systems.

102 Roman law was a compulsory subject in Vietnam law schools' curriculum for several decades. Prior to 2012, at Vietnam National University School of Law in Hanoi, Roman law was taught in the second year as a mandatory, fundamental course. See VIETNAM NATIONAL UNIVERSITY, HANOI-SCHOOL OF LAW, http://law.vnu.edu.vn /abipoly_59/421/content-khung-chuong-trinh-dao-tao-dai-hoc-nganh-luat-hoc-ap-dungcho-cac-khoa-k52 (last visited Mar. 14, 2014). From 2012, Roman law became an optional course. See VIETNAM NATIONAL UNIVERSITY, HANOI-SCHOOL OF LAW, http://law.vnu.edu.vn/abipoly_59/659/content-khung-chuong-trinh-dao-tao-chuan-trinhdo-dai-hoc-nganh-luat-hoc-ap-dung-cho (last visited Mar. 14, 2014). Further, the law schools in Vietnam continue to impose curriculum that "is still modelled on the Sovietera 'state and law' principles." Toope, supra note 94 at 414.

103 CODE JUST.

104 See Kenneth S. Culotta, Forma Cinco? Getting the Benefits of Form 5 in Latin American Mining Ventures, 39 RMMLF-INST 9, § 9.02(2)(a) (1993) (observing that 
the country is slowly moving from the central-planning economy to a more market-based economy, Vietnam continues to hold on to its "civil law legal system" roots. ${ }^{105}$ The French brought the "civil law legal system" roots to Vietnam when they colonized the country. ${ }^{106}$ Instead of ridding itself of French influence, Vietnam embraced the "civil law legal system" tradition. ${ }^{107}$ Moreover, Vietnam closely followed another civil law country, Japan, ${ }^{108}$ in drafting its Civil Code ${ }^{109}$ despite knowing that the Japanese legal system "is deeply flawed." 10

Thus embracing the civil law legal system, Vietnam presented to its people and to the world a Civil Code that embodied a Roman law approach. ${ }^{111}$ The Civil Code is the equivalent of one-stop

"[s]till the basis for most western civil law, the Corpus Juris was classical antiquity's greatest attempt to create a comprehensive system of written law designed to govern all human relationships."); see also M. Read Moore, Tax and Estate Planning Issues for U.S. Clients Who Own Foreign Property, SU036 ALI-CLE 395, II(A)(3)(a) (2013) ("The civil law system derives from Roman law and the Corpus Juris Civilis of the Emperor Justinian. Most of the civil law countries have taken the path of enacting codes of law that reflect general legal principles."); S. Colin G. Petry, The Regulation of Common Interest Developments $s$ It Relates to Political Expression: The Argument for Liberty and Economic Efficiency, 59 CASE W. RES. L. REv. 491, 500 n.52 (2009) (noting that the French Napoleon Code of 1804 was "based heavily on the Corpus Juris Civilis").

105 See Carol V. Rose, The "New" Law and Development Movement in the PostCold War Era: A Vietnam Case Study, 32 L. \& SoC'Y Rev. 93, 97 (1998) ("Vestiges of the French legal system also persist in Vietnam.").

106 See id. at 96.

107 See id. at 97 (noting the "formal hierarchy of statutory laws in Vietnam, for example, mirrors that used in the French legal hierarchy, as does Vietnam's reliance on a civil code.").

108 See Philip J. McConnaughay, Rethinking the Role of Law and Contracts in EastWest Commercial Relationships, 4I VA. J. INT'L L. 427, 430 (2001) (observing that "Japan's more-than-a-century-old civil code essentially replicates the late nineteenthcentury German Civil Code ....").

109 See Veronica L. Taylor, New Markets, New Commodity: Japanese Legal Technical Assistance, 23 WIS. INT'L L.J. 251, 265 (2005) (“[T]he [Civil] Code drafting projects in Vietnam and Cambodia are perceived by Japanese participants as the most important legal technical assistance projects carried out by Japan to date.").

$110 \mathrm{Id}$. at 273 ("Japan's legal system is deeply flawed, while simultaneously expanding legal technical assistance abroad on the basis that Asian developing economies have much to learn from Japan's legal evolutionary path.").

111 The Vietnam Civil Code, a body of laws, resembles what Roman Emperor Flavius Petrus Sabgatius Justinianus (Justinian) (483-565), had done: "compil[ing] all Roman law into one coherent body, the Corpus Juris Civilis ...." Erik J. Krueger, God Versus Government: Understanding State Authority in the Context of the Same-Sex Marriage Movement, 7 LIBERTY U. L. REV. 235, 246 n.79 (2013). 
shopping for all laws that have significant impact upon society. Indeed, the Civil Code ambitiously provides and controls "legal status, legal standards for the conduct of individuals, legal persons," 112 as well as their "rights and obligations of subjects regarding personal identities and property in civil, marriage and family, business, trade, [and] labor relations (hereinafter referred collectively to as civil relations)." 113 It sets forth "the tasks of protecting legitimate rights and interests of individuals and organizations, State interests and public interests" for the purposes of "ensuring legal equality and safety in civil relations, contributing to the creation of conditions for meeting the material and spiritual demands of people, and for the promotion of socioeconomic development."114 Its massive scope places its importance in renewing the entire Vietnam legal system. As seen in its preamble, the Civil Code "holds an important position in the legal system of the country, creates a legal basis for the purpose of freeing up all production capabilities, promoting democracy and ensuring social equality and human civil rights."115 The Civil Code is viewed internally by the Vietnamese as "just slightly less important "than the Constitution.","16

A closer look at the Civil Code reveals 777 articles. ${ }^{117}$ Together, the articles encompass a vast and comprehensive body of laws. For example, the Civil Code covers laws relating to civil obligations, civil legal capacity, personal rights, guardianship, death, missing persons, legal persons, family households, cooperative groups, contract transactions, representations, time

112 C. Civ. art. I (Viet.).
113 Id.
114 Id.
115 C. CIV. (1995) (Viet.). The preamble asserts that the Civil Code will "contribute to ensuring a stable and wholesome communal life and to preserving and promoting the traditions of unity, mutualism and co-operation, good morals and customs and national cultural characteristics developed during the long history of building and protecting the Fatherland Vietnam, and to creating a multi-sector commodity economy operating in the market-oriented mechanism under the management of the State and in accordance with the socialist orientation, and fulfilling the objectives of a prosperous people, a strong nation, and an equitable and civilized society."

116 Vietnamese Rights Laid Out in New Civil Code, N.Y. Times (Oct. 29, 1995), available at http://www.nytimes.com/1995/10/29/world/vietnamese-rights-laid-out-innew-civil-code.html (quoting National Assembly spokesman, $\mathrm{Vu}$ Mao on the significance of the new Civil Code).

117 C. Civ. (Viet.). 
limits, time limit calculations, property and ownership rights, civil obligations and civil contracts, security for the performance of civil obligations, sales of houses, leases, contracts for renting a house, contracts for transportation, services contracts, processing contracts, promise of rewards and competition prizes, obligations to return property, liability to compensate outside of contracts, damages, compensations for damages caused by specific persons and events, inheritance, testamentary inheritance, inheritance at law, transfer of land use rights, intellectual property and technology transfers, civil relations involving foreign elements, among many other topics. ${ }^{118}$

In other words, imagine all property law, torts law, contract law, the Uniform Commercial Code, trust and estate law, family law, patent law, trademark law, copyright law, remedies, and litigations pulled together into a single code, the Civil Code, promulgated at the same time with all 777 articles linked together. It is simply unfathomable to design a single code with that broad and daunting of a scope at the beginning of the twenty-first century.

There is no rational basis today for such legislative drafting of a massive Civil Code. ${ }^{119}$ Each separate area of law, such as property or torts, is itself very complex as new transactions relating to property and torts occur daily. In some instances, an off-shoot from an existing area of law can be developed into an entirely new area of law; for example, trademark infringement and unfair competition law originated in torts. Each separate area of law needs to grow and change as it continues to codify new relations and transactions dictated by daily life and commerce. Chaining massive areas of laws together restricts their development and flexibility and means that they all stand still or all move together at the same time. Thus, amending each individual area of law will require unlocking the chain that binds them together in the first place.

118 Id.

119 For an example of how some countries separate their laws, see Richard Pedone and Henry Liu, The Evolution of Chinese Bankruptcy Law and Challenges of a Growing Practice Area, http://www.nixonpeabody.com/files/China_Bankruptcy_Law_Pedone.pdf China, one of Vietnam's neighbors has decided to develop many special laws, such as Property Law, Marriage Law, Adoption Law, Succession Law, Patent Law, Copyright Law, Contract Law, Law of Rights in Rem, Law of Tort Liability, Bankruptcy Law, among others. China does not combine all these laws into a single Civil Code. 


\section{IV.The Placement Of Secured Transactions Law Within The Civil Code}

Vietnam views secured transactions as "civil" in nature. The law related to secured transactions has not escaped Vietnam's desire to maintain one code for all things civil. In the 1995 Civil Code, Vietnam embedded secured transactions inside the Civil Code. ${ }^{120}$ Vietnam envisioned secured transactions merely as "civil obligations and civil contracts"121 without considering the availability of credit and financing in a growing economy. Thus, Vietnam failed to grasp the purposes of secured transactions by placing secured transactions law buried inside several layers of the Civil Code.

The 1995 Civil Code is divided into seven Parts, each Part is subdivided into Sections, and each Section is further divided into Articles. ${ }^{122}$ Deep in Part III under the heading "Civil Obligations and Civil Contracts", secured transactions can be found in Section 5 under the subheading "Guarantee for the Performance of Civil Obligations." ${ }^{23}$ Pertinent secured transactions provisions are in Articles 329 to $393 .^{124}$

Structurally, Part I is devoted to "General Provisions" with Articles 1 to $180 .{ }^{125}$ Part II governs "Property and Ownership" within Articles 180 to $285 .{ }^{126}$ Part III encompasses "Civil Obligations and Civil Contracts," and occupies Articles 286 to 393. ${ }^{127}$ Part IV regulates "Inheritance," and runs from Article 394 to $634{ }^{128}$ Part V "Provisions on Transfer of Land Use Right" includes Articles 635 to $744 .{ }^{129}$ Part VI "Intellectual Property Rights and Technological Transfers" contains Articles 745 to 825. ${ }^{130}$ Part VII "Civil Relation Involving Foreign Factors"

120 C. CIv. pt. $3 \S 5$ (1995) (Viet.).

121 See C. Civ. pt. 3 (1995) (Viet.); see also C. CIV. (Viet.) pt. 3 (using the same terminology of "civil obligations" and "civil contracts").

122 C. CIV. (1995) (Viet.).

123 C. CIV. pt. 3 \$ 5. (1995) (Viet.).

124 Id. at arts. 329-93.

125 Id. at pt. 1.

$126 \mathrm{ld}$. at pt. 2.

127 Id. at pt. 3.

128 Id. at pt. 4.

129 C. Civ. pt. 5 (1995) (Viet.).

130 Id. at pt. 6. 
comprises Articles 826 to $838 .^{131}$

After the promulgation of the 1995 Civil Code, Vietnam took the next ten years to amend the entire Civil Code. ${ }^{132}$ A careful examination of secured transactions law in the 2005 Civil Code reveals the same placement scheme. ${ }^{133}$ Despite some revisions, the structure and content of secured transactions law remains the same antiquated, opaque, and incomplete body of law. ${ }^{134}$

The placement of secured transactions law inside the Civil Code makes any meaningful and timely revisions to secured transactions law difficult, as proposed revisions must wait for the entire Civil Code to be revised simultaneously. ${ }^{135}$ Moreover, placing secured transactions law under the "Civil Obligations and Contracts" Part of the Civil Code limits the purposes and scope of financing and credit availability. The drafters failed to understand that secured transactions are not just about civil obligations and contracts, but also property rights and the use of existing and new property, as well as assets and rights to increase the availability of credit and financing. Without a legal framework to permit individuals and entities to leverage their property, assets, and rights, which would encourage creditors to rely on property, assets, and rights for financing, the economy will not be able to grow as credit is not available.

The failure to appreciate the purposes and importance of secured transactions ultimately led to the creation of an antiquated, opaque and incomplete body of secured transactions law.

131 Id. at pt. 7.

132 C. Civ. (Viet.).

133 Id. at pt. $3 \S 5$.

134 Id.; see also C. CIV. pt. $3 \S 5$ (1995) (Viet.) (lending its layout for secured transactions law to the revised version of the code).

135 Vietnam has not amended its Civil Code since 2005, and is now pursuing an ambitious, significant revision of the Code. See Ministry of Justice of Vietnam, Draft Memorandum on the Submission of the Draft Amended Civil Code to the Government 7 (2014), available at http://www.moj.gov.vn/dtvbpl/Lists/Danh\%20sch\%20d\%2 0tho/View_Detail.aspx?ItemID $=216$ (Viet.) (stating that the amendment to the current Civil Code will be "substantial" and "comprehensive"). The scope of amendment includes the provisions on secured transactions. See id. at 11 (explaining the revised provisions on security rights). 


\section{The Antiquated Opaque Law}

\section{A. Antiquated Secured Transactions Law}

Today, Vietnam's secured transactions law still holds on to the antiquated security devices such as "mortgage" and "pledge" which are rooted in ancient Roman law, ${ }^{136}$ while the world has shifted to the unitary approach. ${ }^{137}$ The United States was the pioneer in abolishing the distinction among security devices more than fifty years ago and adopting a unitary concept of "security interest" ${ }^{\prime 138}$ in Article 9 of the UCC. Article 9 later served as a model for secured transactions law reforms worldwide at both national and international levels, most notably, the UNCITRAL Legislative Guide on Secured Transactions. ${ }^{139}$

Despite the global trend, under Vietnamese law the ancient separate security devices still exist. A "secured transaction" is a civil transaction, agreed upon by the parties or provided by law, in which a security device stated in the Civil Code is employed. ${ }^{140}$ The Civil Code enumerates the following seven security devices: pledge, mortgage, deposit, security collateral, escrow account, guaranty, and pledge of trust. ${ }^{141}$ Consequently, any transaction which in nature creates a security right but does not fall into one of these seven devices, is not recognized as a "secured transaction," such as a financial lease or a sale with retention of title.

The antiquated approach detailed above is now maintained in

136 See generally Donald E. Phillipson, Note, Development of Roman Law on Debt Security, 20 STAN. L. REV. 1230 (1968) (tracing the history of security devices in ancient Roman law).

137 See supra Part 1, for discussion of the unitary approach (outlining the key features of a modern secured transactions system).

138 See U.C.C. $\$ 1-201(35)$ (defining "security interest" as any "interest in personal property or fixtures which secures payment or performance of an obligation").

139 See Ryan E. Bull, Note, Operation of the New Article 9 Choice of Law in an International Context, 78 TEX. L. REV. 679, 680 (2000) (stating that Article 9 has served as a model for secured credit provisions in both developing and established nations); see also LeGISLATIVE GUIDE, supra note 8,9103 , at 56 (acknowledging that the idea of creating a single, unified regime of security right in movable assets originated from the U.C.C., and later spread to other countries and was followed by the OAS Inter-American Model Law on Secured Transactions as well as the EBRD Model Law on Secured Transactions).

140 C. CIV. art. 323, $\uparrow 1$ (Viet.).

141 C. Crv. arts. 318, 326, 342, 358-61, 372-73. (Viet.) 
the civil codes of many civil law countries, ${ }^{142}$ which Vietnamese lawmakers are more familiar with and more willing to accept. Vietnamese legal scholars and government officials involved in drafting the Civil Code were trained in civil law countries such as France, Germany, and Japan, and carried on the outdated knowledge of secured transactions law. ${ }^{143}$ As a result, the 200year-old French Civil Code ${ }^{144}$ and the over-100-year-old Japanese Civil Code ${ }^{145}$ were selected as the preferable models for crafting the provisions on secured transactions in the Vietnamese Civil Code $^{146}$ based on the faded glory that these codes achieved in the $19^{\text {th }}$ century. Meanwhile, the highly acclaimed Japanese Civil Code was unable to solve the problem of access to credit even in its own country, much less in Vietnam, ${ }^{147}$ and legislators in Japan looked to Article 9 of the UCC for solutions while reforming their own law on secured transactions in $2004,{ }^{148}$ without the knowledge

142 See Ulrich Drobnig, A Comparative Introduction to Security over Movables and Intangibles, in 6 INT'L ECON. DEV. L. SERIES, EMERGING Fin. MKTS. AND SECURED TRANSACTIONS at 5 (Joseph J. Norton \& Mads Andenas eds., Kluwer Law Int'l 1998) (noting that the distinction among different types of security can be called "the European approach"; for example, France has "more than a dozen types of security, spread over as many codes, laws and regulations.").

143 See GiLleSPIE, supra note 20, at 161 (noting that most members of the drafting committee's property law subcommittee for the Civil Code of 1995 were trained in the German Democratic Republic and injected their understanding of the pre-communist German Civil Code into the draft).

144 David Gruning, Codifying Civil Law: Principle and Practice, 51 LoY. L. REv. 57,57 (2005) (noting that the French Civil Code was promulgated in 1804 and now has only a "symbolic value").

145 McConnaughay, supra note 108 (noting that the Japanese Civil Code is over 100 years old).

146 GILlESPIE, supra note 20, at 162 (noting that many provisions of the C. Civ. (Viet.) (1995) were borrowed from the French, Japanese, and Soviet Civil Codes).

147 Taylor, supra note 109, at 273 ("Japan continues to lack self-sufficiency in service sectors such as transnational law and finance... [and] lacks a reliable digital database of statutes and cases and has no complete set of laws translated into English"); see also Souichirou Kozuka \& Naoe Fujisawa, Old Ideas Die Hard?: An Analysis of the 2004 Reformation of Secured Transactions Law in Japan and Its Impact on Banking Practices, 31 T. JEFFERSON L. Rev. 293, 315 (2009) (identifying the existing differences between Japanese secured transactions law and U.C.C. Article 9, including "the formalistically defined scope of application, the requirement of the identification of the secured asset, the lack of rules on the effects of the substantive rights of the secured creditor and the rules on priority").

148 Kozuka \& Fujisawa, supra note 147, at 295 (noting that Japanese lawmakers also referred to U.C.C. Article 9 in the course of debates before the reform of their secured 
of the Vietnamese Civil Code drafters.

Vietnam is now facing similar problems encountered by the United States a century ago due to the distinction among security devices. ${ }^{149}$ Distinguishing one security device from another creates confusion and severely limits the scope of secured transactions. ${ }^{150}$ The courts in Vietnam are frequently confused between "mortgages" and "guaranty" when the mortgagor (the debtor) is not the obligor, ${ }^{151}$ but rather a third party who mortgages its property to secure the obligation of the obligor. In those cases, the courts have declared the security agreement void and insisted that it must be titled "guaranty contract" instead of "mortgage contract," causing grievances and resentment from the secured party. ${ }^{152}$ On the other hand, some courts have enforced security agreements which were mislabeled "pledge contract" instead of "mortgage contract" even though the secured party did not take possession of the collateral as required in a pledge. ${ }^{153}$ The inconsistent treatment of the courts towards misnamed security agreements demonstrates that the distinction among security

transactions law).

149 See Grant Gilmore, The Secured Transactions Article of the Commercial Code, 16 L. \& CONTEMP. PROBS. 27, 29-32 (1951) (discussing the problems of the pre-U.C.C. independent security devices).

150 Id.

151 See C. Civ. art. 280. (Viet.)

152 Truong Thanh Duc, Nhung Vuong Mac Trong Thuc Tien Ap Dung Cac Quy Dinh Ve Bao Dam Thuc Hien Nghia Vu Dan Su Va Mot So Kien Nghi - Nhin Tu Goc Do Cac To Chuc Tin Dung [Comments on Difficulties in Applying the Legal Provisions on Security for Performance of Obligations and Proposed Solutions from the Banks' Perspective] (Presentation at the Conference of the Ministry of Justice of Vietnam on "Identifying Legal Aspects of Real Security Rights and Proposals to Improve the Vietnamese Civil Code," Hanoi, Vietnam, June 27, 2013) (citing to a number of court decisions declaring a mortgage was void because it was labeled "mortgage" instead of "guaranty" when the mortgagor was not the obligor, such as Judgment No. 26/2011/KT. ST (Quang Ngai Provincial People's Ct. Aug. 5, 2011) and Judgment No. 05/2011/KDTM-PT (Da Nang App. Div. of the Sup. People's Ct. Nov 25, 2011)).

153 See, e.g., SeaBank v. MBH Med. Devices Joint Stock Co., Judgment No. 59/2012/KDTM-ST (Hanoi People's Ct. June 18, 2012) (Viet.) (on file with the authors) In this case, the debtor and the bank signed a "pledge contract" in addition to a loan agreement whereby the debtor "pledged" the medical devices to be acquired with the loan to secure its payment obligation, but the medical devices were not in the bank's possession, and were leased to a hospital by the debtor. However, the court still enforced the security agreement despite the fact that it was mislabeled "pledge contract" instead of "mortgage contract." See id. 
devices based on the name of the transaction is unnecessary, confusing, ill-suited, and contrary to the financing practice. After all, the secured party does not care how the security agreement is entitled, as long as it has a security interest in the debtor's property to make sure that when default occurs, the secured party can foreclose on the property to recover the debt and has priority over competing claimants.

Another consequence of the rigid distinction amongst security devices is the exclusion of many transactions from the scope of "secured transactions," such as financial leases and conditional sales (sales with retention of title). ${ }^{154}$ Financial leases are now governed by a separate set of rules, ${ }^{155}$ and in disputes concerning the lessee's default on its payment obligation and foreclosure on the leased property, the rights and duties of the lessor ("secured party") and the lessee ("debtor") are not duly protected because the transaction does not fit into any of the seven security devices under the Civil Code. ${ }^{156}$ Therefore, financial leases are placed outside the province of secured transactions law, even though they are recognized by specialized laws as a form of advancing credits. ${ }^{157}$ For example, in one financial lease contract dispute, the court held that the leased property was not "collateral" under secured transactions law, meaning the disposition of the leased

154 See C. CIV. art. 318. (Viet.)

155 See Decree No. 39/2014/ND-CP On Operation of Financial Companies and Financial Leasing Companies (May 7, 2014) (Viet.): see also Joint Circular No. 08/2007/TTLT-NHNN-BCA-BTP Guiding the Recovery and Disposal of Financially Leased Assets by Financial Leasing Companies, Ministry of Justice (Dec. 10, 2007) (Viet.) (providing guidance on repossession and foreclosure on financial leased property by financial leasing companies).

156 See C. Civ. art. 318. (Viet.)

157 See Decree On Operation of Financial Companies and Financial Leasing Companies art. 3. ("7. Financial leasing means medium-term and long-term credit activities based on financial leasing contracts between the lessors and the lessees. The lessors commit to buying assets for financial leasing at the request of the lessees and hold the ownership over financially leased assets during the lease term. The lessees use the leased assets and pay rents therefor during the lease term under the financial leasing contracts."). The Decree does not address the status of a financial lease which bears features of a sale with retention of title; for example, the lessee has the option to purchase the leased asset at the end of the lease term for a nominal price, or title to the leased asset is transferred to the lessee automatically at the end of the lease term. See

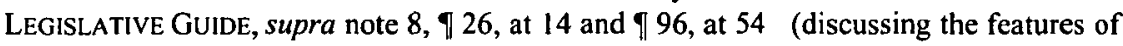
financial leases that fall under the scope of secured transactions covered by the Legislative Guide). 
property did not have to follow the requirements of secured transactions law. ${ }^{158}$ In fact, many disputes arising from financial leases concerned the disposition of the leased property upon the lessee's default, such as whether the lessor's failure to give notice of disposition to the lessee rendered the disposition invalid or discharged the lessee from the lessor's deficiency claim. ${ }^{159}$ These kinds of disputes are no different than those arising from pledges or mortgages. In those cases, the courts had to rule on the disposition and deficiency issue without any legal grounds except the provisions in the lease contract itself, because the courts could not apply secured transactions law to financial leases, and specialized laws on financial leases are incomplete as to disposition, notice, and distribution of the sale proceeds. ${ }^{160}$ Without a unitary approach to secured transactions, independent sets of rules will continue to govern transactions which bear the same nature of securing an obligation, causing uncertainty for the parties and failing to provide adequate rules to resolve disputes.

158 See Binh Dinh Transp. Shipbuilding Joint Stock Co. v. Vietcombank Leasing Ltd. Co. et al., Judgment No. 56/201 1/KDTM-ST (Hanoi People's Ct. Apr. 19, 2011) (Viet.). In this case, the lessee sued the lessors for wrongfully disposing of the leased property by failing to sell the leased property on auction and prayed the court to invalidate the sale of the property and return the property to the lessee. The lessee signed a financial lease contract with two leasing companies whereby the lessors provided financing for the lessee to acquire a vessel in the form of a lease with monthly lease payments for a sevenyear term. The lessee had paid $60 \%$ of the purchase price before it defaulted on payments. The lessors terminated the lease and repossessed the vessel. The lead lessor then hired an appraisal company to determine the value of the vessel, but the debtor objected to the appraised value, asserting that the appraisal was too low compared to fair market value. Despite the debtor's objection, the lessors sold the vessel to a third party at the price equal to the appraised value. In addition to the claim to invalidate the sale, the lessee also claimed damages resulting from the lessors' conversion of the lessee's oil and assets attached to the vessel at the time of repossession. The lessors counterclaimed for deficiency. The court ruled in favor of the lessors as to the sale of the vessel and the deficiency claim but held for the lessee as to the conversion claim. The court's reasoning was mainly based on the lease contract provisions and the law governing financial leases, which does not require the lessors to sell the leased property on auction. Id.

159 See, e.g., Vietinbank Leasing Co., Ltd. v. Hoang Sa Joint Stock Co., Judgment No. 13/2012/KDTM-PT, 3, (Hanoi App. Div. of the Sup. People's Ct. Feb. 8, 2012); BIDV Leasing Co., Ltd v. Quynh Phuong Trading Co., Ltd., Judgment No. 2109/2011/KDTM-ST, 9, (Ho Chi Minh City People's Ct. Dec. 6, 2011) (Viet.) The lessor refused to pay for deficiency because it did not receive notice of disposition of the leased property, and because the sale price was lower than fair market value. Id.

160 See Decree On Operation of Financial Companies and Financial Leasing Companies. 
Similarly, conditional sales or sales with retention of title, without the status of "secured transactions," pose high risks and burdens on the seller, discouraging sales on credit and stifling consumption, production, and trade. The unpaid seller often remains an unsecured creditor or has to seek a different source of security, usually real property owned by the buyer or a third party. This practice hinders secured financing because not many buyers have available real estate to secure their payment obligations under the sale contracts with their suppliers to acquire inventory or to purchase consumer goods. Due to the scarcity of collateral, the buyer often persuades relatives or friends to provide a third-party mortgage to the seller. ${ }^{161}$ For example, in a contract for the sale of timber valued at 4.4 billion VND (approximately 200,000 USD) between two companies, to secure its payment obligation, the buyer - instead of using the timber itself as collateral - sought a third-party mortgage from two individuals, who later fraudulently transferred the mortgaged property to another party. ${ }^{162}$ The seller (secured party) had to bring a lawsuit not only to foreclose on the mortgage but also to declare the transfer void. ${ }^{163}$ All of the costs and burdens on the seller could have been avoided if the law explicitly treated the unpaid seller with retention of title as a secured party with all available remedies under secured transactions law.

\section{B. Opaque, Inconsistent and Contradictory Secured Transactions Law}

Vietnam's secured transactions law is not only antiquated but is also opaque and inconsistent. The inconsistency occurs at multiple levels, within the Civil Code itself and between the Civil Code and the regulations implementing the Code, creating a selfcontradictory body of secured transactions law.

The distinction among seven security devices is obscure and confusing due to the lack of a common thread dictating the Civil Code provisions on secured transactions. Without considering that the fundamental policy of secured transactions law is to encourage

161 See, e.g., Hanoi Leather Imp.-Exp.\& Inv. Joint Stock Co. v. Kim Duong Equip. \& Material Joint Stock Co., Judgment No. 55/2012/KDTM-ST (Hanoi People's Ct. May 30,2012 ) (Viet.) (on file with the authors).

$162 \mathrm{See} i d$. at 2-5.

163 Id. 
secured financing and increase the availability of credit, the drafters of the Civil Code embraced devices that do little to further such policy, and instead exacerbate the opacity. For example, a transaction in which a potential buyer puts down a small amount of "deposit" or "earnest money" to secure its entry into a sale contract is not a secured transaction for the purpose of advancing credit. ${ }^{164}$ Similarly, personal security devices such as "guaranty" and "pledge of trust" do not play any significant role in encouraging secured financing and maximizing the value of property, because no collateral is involved in a guaranty or pledge of trust transaction. ${ }^{165}$ Additionally, some devices overlap with each other; for instance, an "escrow account" is, in practice, no different than a "pledge" because both "escrow account" and "pledge" require the debtor to deliver the collateral to the secured party to secure an obligation. ${ }^{166}$ Therefore, the list of security devices in the Civil Code is inadequate, and on the other hand, is opaque and redundant. Moreover, while financial leases and sales with retention of title are not recognized as "secured transactions," the law requires that the lessor or the seller with retention of title register the financial lease or the sale at a registration office for secured transactions to obtain priority against other secured parties. ${ }^{167}$ Despite this registration requirement, due to the rigid separation among security devices, the courts never treat financial leases and conditional sales as secured transactions.

The law also fails to make a clear distinction between attachment and perfection and does not specify the requirements for attachment. ${ }^{168}$ Hence, the parties and the courts still think that

164 See C. CIV. art. 358 (Viet.) ("Deposit is an act whereby one party transfers a sum of money or precious metals, gems or other valuable things ... to another party for a specified time limit to secure the entry into, or the performance of, a civil contract.").

165 See C. CIV. arts. 361-73 (Viet.).

166 See C. Civ. arts. 326, 360 (Viet.) (comparing "pledge" and "escrow account" with an escrow account being similar to pledge in that the debtor parts with possession of his or her tangible assets (money, commercial paper, precious stones, or gold), and a third party (a bank) is in control of such assets for the benefit of the secured party.).

167 Decree No. 163/2006/ND-CP On Secured Transactions, (Dec. 29, 2006) (Viet.) (amended Feb. 2, 2012 by Decree No. 11/2012/ND-CP Amending and Supplementing Several Provisions of Decree No. 163/2006/ND-CP On Secured Transactions), art. 13.

168 See C. CiV. art. 122 (Viet.) (implying the following requirements: (1) the secured transaction must comply with the requirements for an effective civil transaction under Article 122 of the 2005 Civil Code; (2) the collateral must be of the kind that the law does not prohibit to be traded; (3) the debtor must have rights in the collateral; (4) there 
the purpose of registration (filing) is to make a secured transaction effective against the debtor rather than to obtain priority. ${ }^{169}$ More severe consequences occur from the vague attachment requirements. For example, a court can arbitrarily declare a secured transaction void due to the parties' failure to name the correct security device. As mentioned above, in cases where the mortgagor was not the obligor, but a third party, the courts held the security agreement void for being mislabeled as "mortgage contract" instead of "guaranty contract." 170 A security agreement has also unreasonably been declared void due to the absence of a clear provision on whether the debtor must own the collateral or only needs to have some right in the collateral, for the secured transactions to be enforceable. ${ }^{171}$ In another case, the court

must be a security agreement, either oral or written, between the parties; $(5)$ pledge is effective only when the collateral is delivered to the pledgee; and (6) certain secured transactions are only effective when they meet the formality requirements, such as filing or notarization.).

169 See, e.g. SeaBank v. MBH Med. Devices Joint Stock Co., Judgment No. 59/2012/KDTM-ST (Hanoi People's Ct. June 18, 2012) (Viet.) (on file with the authors). In this case, although the secured party only sought to enforce the security agreement against the debtor and there was no priority dispute, the court held that the security agreement was enforceable because it was duly executed by the parties and was properly registered at the relevant registration office for secured transactions involving movable assets.). Id.

170 See Truong Thanh Duc et al., supra note 152.

171 See Phuong Nam Joint Stock Commercial Bank v. Doan Minh Ha, Judgment No. 1234/2012/KDTM-ST (Ho Chi Minh City People's Ct. Aug. 22, 2012) (Viet.) (on file with the authors). In this case, the bank loaned 42 billion VND (approximately 2 million USD) to an individual obligor and the debtor pledged more than 4.65 million shares valued at 46.5 billion VND to secure the obligor's payment obligation. The debtor executed a pledge contract and an agreement to transfer the shares to the bank. One day after the execution of such commitment, the debtor's wife signed a document verifying that the shares were owned solely by the debtor. The chairman of the board of directors of the company whose shares were pledged by the debtor also signed a document verifying that the debtor owned the shares. Relying on those documents, the bank accepted the shares as collateral and advanced the loan. The debtor and his wife later got divorced, but they had not disposed of their common property. When the obligor defaulted on the loan, the bank attempted to foreclose on the collateral. The debtor and his ex-wife objected, contending that the shares were commonly owned by them at the time of attachment, and since the ex-wife had not signed in the pledge contract and the share transfer agreement, these contracts should be void. They also raised another argument that the transfer of shares was subject to restrictions under the Law on Enterprises and other regulations. The court ruled in favor of the debtor and his ex-wife. Thus, the bank, from a secured creditor, suddenly became an unsecured creditor for a total outstanding debt of 63.3 billion VND ( 3 million USD). The court also ruled that 
dismissed the bank's claim to recover debt and to foreclose on the collateral, which comprised three pieces of construction equipment, because the bank could not submit the original certificates of title of the equipment together with the complaint. ${ }^{172}$

The Civil Code contains various provisions restricting the use of property as collateral, but the regulations implementing the Code provide to the contrary, causing internal inconsistencies within secured transactions law. ${ }^{173}$ For instance, under the Civil Code, the debtor must own the property in order for it to serve as collateral. ${ }^{174}$ The ownership requirement in the Civil Code is inconsistent with modern secured transactions law and severely limits the availability of credit. ${ }^{175}$ The regulations, however, recognize that the debtor may collateralize property to which the debtor does not have title. ${ }^{176}$ Another example of the inconsistency is that the Civil Code requires the value of the collateral to exceed the total value of secured obligations if the collateral secures multiple obligations, ${ }^{177}$ while the regulations provide that the value of the collateral may be equal to, less than, or greater than, the total value of secured obligations. ${ }^{178}$ These contradictions make it difficult for the parties to determine which law applies: the restrictive Civil Code, which is the superior authority, or the more liberal regulations.

both the debtor and the bank were at fault to cause the pledge contract and the share transfer agreement void; therefore, no party could claim damages against the other party. As a result, the debtor can avoid liability and take the collateral away from the secured party. Although the secured party was also at fault when failing to conduct due diligence about the collateral, the court ignored the fact that the debtor still had half interest in the collateral and that he had engaged in fraudulent conduct by presenting documents representing that he had full power to transfer the collateral to the bank. Id.

172 See Techcombank v. Ba Dinh Constr. \& Trading Joint Stock Co., Order of Dismissal No. 141/2012/QDST-KDTM (Hanoi People's Ct. Sept. 21, 2012) (Viet.) (on file with the authors).

173 See C. Civ. arts. 320-22, 324 \& 1 (Viet.).

174 C. Civ. arts. 320-22 (Viet.).

175 See U.C.C. $\S 9-203$ (b)(2)(2010) (requiring only that the debtor have rights in the collateral or power to transfer rights in the collateral for the purpose of attachment of the security interest).

176 Decree on Security Transactions art. 13 (providing that property purchased on deferred payment or installment payments and property leased for more than one year can be used as collateral).

177 C. CIV. art. $324 \S 1$ (Viet.).

178 Decree on Security Transactions art. 5. 
Many provisions in the Civil Code exist without a justified reason, contradict themselves, and run counter to modern secured financing practices. For example, the Code provides that the mortgagor has the duty to notify the mortgagee of any third party's rights in the mortgaged property; in case of failure to provide such notice, the mortgagee has the right to cancel the mortgage contract and demand compensation for damages or maintain the contract and accept the rights of the third party in the mortgaged property. ${ }^{179}$ A similar duty is imposed on the pledgor. ${ }^{180}$ These provisions render the provision on registration of secured transactions meaningless, because it is the secured party's responsibility to conduct due diligence and discover any third party's rights in the collateral by searching registration records. ${ }^{181}$ Furthermore, under the Code, the mortgagor is not allowed to sell, trade, or donate the mortgage property as a gift without the mortgagee's consent, unless the mortgaged property is inventory. ${ }^{182}$

\section{The Incomplete Law: Missing Property Collateral, Perfection, Priority and Remedies}

A voluminous civil code with an expansive scope cannot provide complete rules for each area of law that it covers. Generality is the main feature of any civil code. ${ }^{183}$ The absence of specific rules is inevitable. With respect to secured transactions law, Vietnam's Civil Code leaves numerous gaps in property collateral, perfection, priority, and remedies.

\section{A. Missing Property Collateral}

Vietnam's secured transactions law lacks a sound classification

179 C. CIV. art. $348 \S 3$ (Viet.).

$180 \mathrm{C}$. CIV. art. $330 \S 2$ (Viet.) ("[The pledgor has the duty] to notify the pledgee of any third party's rights in the pledged property, and in case of failure to provide such notice, the pledgee has the right to cancel the pledge contract and demand compensation for damages or maintain the contract and accept the rights of the third party in the pledged property").

181 C. Civ. art. 323 (Viet.) (providing general rules on the effect of registration of secured transactions).

182 C. CIV. art. $348 \S 4$ (Viet.).

183 See Arthur T. Von Mehren, Some Reflections on Codification and Case Law in the Twenty-First Century, 31 U.C. DAvis L. Rev. 659, 668 (1998) (noting that the codes in civil law systems typically embrace a "relatively high degree of generalization"). 
of collateral and simply sets forth a lengthy yet incomplete list of the kinds of property that can serve as collateral. ${ }^{184}$ The Civil Code enumerates the following kinds of collateral: objects (tangible things), monies, valuable papers (such as monies, bonds, shares, promissory notes), and property rights (including property rights arising from copyrights, industrial property rights, rights to plant varieties, the right to claim debts, the right to receive insurance indemnities for secured objects, property rights to capital amounts contributed to enterprises, property rights arising from contracts, land use rights, and the right to exploit natural resources). ${ }^{185}$ There is no distinction between consumer goods, inventory, farm products, and equipment. The law does not

184 See infra $\mathrm{n} .185$.

185 C. Crv. arts 320-22. See also Thông Tu Số: 05/2011/TT-BTP Hướng dẫn một số vấn đề về đăng ký, cung cấp thông tin về giao dịch bảo đảm, hợp đồng, thông báo việc kê biên tài sản thi hành án theo phương thức trực tiếp, bưu điện, fax, thư điện tử tại Trung tâm Đăng ký giao dịch, tài sản của Cục Đăng ký quốc gia giao dịch bảo đảm thuộc Bộ Tu pháp [Circular No. 05/2011/TT-BTP, Guiding a Number of Matters on Registering, Supplying of Information on Security Transactions, Contract, Written Notice of Distrain Assets for the Performance of Judgment in the Direct Manner, Post office, Fax, Email at the Registration Center on Transactions, Assets of the National Registry of Secured Transaction] Ministry of Justice (Feb. 16, 2011) (Viet.) (hereinafter Circular 05) available at http://www.moj.gov.vn/vbpq/Lists $/ \mathrm{Vn} \% 20 \mathrm{bn} \%$ 20php\%20lut/View_Detail.aspx?ItemID=26308.

Circular 05 provides a more specific list of movable assets that can be used as collateral, which comprises:

-Automobiles, motorcycles, other road motor vehicles; railway vehicles;

-Fishing vessels; in-land water vehicles;

-Machinery, equipment, raw materials, fuel, materials, consumer goods, other goods,

precious metals, precious stones;

-Vietnamese currency, foreign currency;

-Stocks, bonds, promissory notes, payment orders, certificates of deposit, fund certificates (fund stocks), checks, and other valuable papers that have monetary value and are allowed to be transacted;

-Rights deriving from copyright, industrial property right, right to plant variety; rights to payment, other rights owned by the securing party deriving from contracts or other legal bases, except land use right and right to ownership of residential house;

-Right to shares or capital contribution in an enterprise or a project;

-Right to exploit natural resources, and money paid for ground-leveling and space clearance used to secure an obligation;

-Profits; collateral insurance proceeds, or other pecuniary benefit deriving from the collateral listed above. 
provide definitions for each kind of collateral. ${ }^{186}$ The absence of collateral classification leads to fragmented and inadequate rules for perfection and priority.

Moreover, many important kinds of collateral are missing, such as letter-of-credit rights, chattel papers, and commercial tort claims. Each enumerated category of collateral embraces a narrow scope, which does not suffice to contain all sub-categories. For example, with regard to securities, only stocks, bonds, and fund certificates are listed, while uncertificated securities and securities entitlements are unmentioned. ${ }^{187}$ The list of intellectual property rights does not cover intellectual property licenses and other rights arising from intellectual property. ${ }^{188}$ In addition, the law is completely silent on fixtures and only covers a general category of "property attached to land," which is typically deemed to be a subset of "immovable property." 189

The rules governing "after-acquired property" are also incomplete and incapable of encouraging the use of revolving collateral in secured financing. Not all property that the debtor acquires after the creation of a secured transaction is characterized as after-acquired property. ${ }^{190}$ After-acquired property only includes the following three types: (1) property acquired with money borrowed from lenders; ${ }^{191}$ (2) property that is being created

186 Only "inventory" and "valuable papers" are defined by the law, but the definitions are very narrow. See Decree on Security Transactions art 3 \& 8 8-9 ("Inventory" covers movable property used to trade, sell, lease in the scope of business of the debtor. "Valuable papers" include stocks, bonds, bills of exchange, promissory notes, certificates of deposit, checks, fund certificates, and other valuable papers provided by law, which have monetary value and are allowed to be transacted.).

187 Cf. U.C.C. \& 9-102(a)(49) (2010) (“'Investment property' means a security, whether certificated or not, security entitlement, securities account, commodity contract, or commodity account.").

188 Compare with U.C.C. $\$ 9-102 \mathrm{cmt}$. 5d (2002) (indicating that intangible collateral also includes "rights that arise under a license of intellectual property, including the right to exploit the intellectual property without liability for infringement").

189 C. CIV. art. $174 \S 1$ (Viet.) (indicating "immovable property" comprises houses and buildings attached to land, "including properties attached to such houses and constructions ... “) (emphasis added).

190 Decree on Security Transactions art. $4 \S 2$ (defining after-acquired property).

191 Generally, a debtor has to specifically identify what he is going to purchase with the loan: a car, a piece of equipment, a certain amount of inventory, or a house; otherwise, the bank will never extend credit. See, e.g. Judgment No. 59/2012/KDTM-ST (Hanoi People's Ct. June 18, 2012) (identifying after-acquired collateral as a specific machine); Judgment No. 19/2012/KDTM-PT (Hanoi App. Div. of the Sup. People's Ct., 
and is unfinished at the time the secured transaction is entered into; ${ }^{192}$ and (3) property that has already come into existence and is of the kind that the law requires registration of ownership but is not registered until after the secured transaction is entered into. ${ }^{193}$ With such a limited scope of "after-acquired property," the law makes it difficult for businesses to use revolving property such as inventory and account receivables as collateral because these kinds of property are constantly replaced by new inventory and account receivables, and therefore do not fit into any type of "afteracquired property" provided above.

Moreover, the concept of "proceeds" virtually does not exist. Proceeds are understood merely as the cash collected from the sale

Feb. 14, 2012) (specifying after-acquired collateral as a certain amount of steel).

192 This type of after-acquired property usually refers to circumstances wherein the debtor borrows money to develop real estate, or to purchase real estate from developers, and such real property is still under construction when the parties enter into the secured transaction. This type may also cover unfinished equipment, inventory, aircraft, vessels, and again, the property must be specified in the security agreement. See Joint Circular 01/2014/TTLT/NHNN-BXD-BTP-BTNMT Providing Instructions on the Procedures for Mortgaging Future-Acquired Houses under the Regulations Specified in the Decree No. 71/2010/ND-CP dated June 23, 2010 of the Government Detailing and Providing Guidance on the Implementation of the Housing Law (issued by the State Bank of Vietnam, Ministry of Construction, Ministry of Justice, and Ministry of Natural Resources and Environment, Apr. 25, 2014) [hereinafter Joint Circular 01] art. 3, I1 (defining "future-acquired house pledged as collateral" means "the house that organization or individual purchases from the real estate businesses who develop the residential property development projects at the period when the home mortgage is brought into effect and such a house is under construction as defined in the approved design and construction license (if required)..."); see also Thế chấp tài sản hình thành trong tưong lai [Mortgage of Future-Acquired Property], http://www.luatdaiviet.vn/xemtin-tuc/the-chap-tai-san-hinh-thanh-trong-tuong-lai (last visited Oct. 3, 2014) (explaining different types of future-acquired property under Decree on Security Transactions).

193 This type refers to property that the debtor already acquires before the security agreement is signed, but the procedure to transfer title from the transferor to the debtor, "the recordation of ownership" has not been completed. This scenario usually occurs when the collateral is real property, or a vehicle that the law requires recordation of ownership. See Joint Circular 01, art. 3, \$1 ("future-acquired house pledged as collateral" also includes "a house [that] has been completely built as prescribed in the construction laws but has yet to receive the Certificate of land tenure, house and fixture ownership"); see also Thế chấp tài sản hình thành trong tương lai [Mortgage of Future-Acquired Property], http://www.luatdaiviet.vn/xem-tin-tuc/the-chap-tai-san-hinh-thanh-trongtuong-lai (last visited Oct. 3, 2014) (explaining different types of future-acquired property under Decree on Security Transactions). 
of the original collateral. ${ }^{194}$ Banks in Vietnam, however, are unaware of proceeds, even in such a narrow meaning, because the law does not make clear what constitutes proceeds and how proceeds are treated with regard to attachment, perfection, and priority. Therefore, banks always feel insecure when taking security interests in inventory and endeavor to guard the inventory instead of controlling the proceeds generated from inventory (account receivables). ${ }^{195}$ Banks usually restrain the debtor from selling its inventory, which not only impedes the free flow of commerce but also precludes the debtor from being able to generate cash and pay off the debts. ${ }^{196}$ Apparently, banks' efforts to guard the collateral rarely succeed, because the debtor inevitably needs to resell his inventory and acquire new inventory. ${ }^{197}$ The absence of a well-developed set of rules for "proceeds" locks up the collateral and opens the door for

$194 C f$. C. CIV. art. $349 \S 3$ (Viet.) (indicating where the mortgaged inventory is sold, the right to demand payment from buyers, proceeds of the sale, or property formed from the proceeds of the sale, become the mortgaged property in substitution for the sold inventory), with U.C.C. $\S 9-102(64)$ (2010) (providing a very broad definition of proceeds, which covers: (1) whatever is acquired upon the sale, lease, license, exchange, or other disposition of collateral; (2) whatever is collected on, or distributed on account of, collateral; (3) rights arising out of collateral (insurance policy); (4) claims arising out of the loss, nonconformity, or interference with the use of, defects or infringement of rights in, or damage to, the collateral; (5) insurance payable by reason of the loss or nonconformity of, defects or infringement of rights in, or damage to, the collateral (to the extent of the value of collateral and to the extent payable to the debtor or the secured party)).

195 See, e.g., Judgment No. 19/2012/KDTM-PT (Hanoi App. Div. of the Sup. People's Ct., Feb. 14, 2012) (Viet.). In this case, the bank, the debtor, and a bailee entered into a bailment agreement whereby the bailee agreed to hold the inventory collateral for the benefit of the bank and to release the inventory only upon the bank's written order. $I d$. at 2 . Only when the debtor was in default did the bank discover that the collateral had already been sold. Id. The bank sued the debtor to recover the debts, and also sued the bailee for damages, claiming that the bailee released the inventory for the debtor to sell without the bank's permission. Id.

196 See id.

197 See id. At trial, the debtor testified that it must sell the inventory immediately before obtaining the bank's permission because the price on the market sharply dropped by $50 \%$. Judgment No. 19/2012/KDTM-PT. It is clear that without an elaborate set of rules governing proceeds, the secured party always feels insecure when accepting revolving collateral such as inventory. In the above case, the bank, instead of controlling the cash flow (account receivables) generated from the inventory, attempted to guard the collateral physically, thus restraining the debtor's flexibility in disposing of its inventory. Id. Moreover, the bank did not understand the concept of proceeds, and incorrectly assumed that its security right terminated when the inventory was sold. Id. 
circumvention and fraud.

Considering the aforementioned gaps in the Civil Code, it is unsurprising that Vietnamese banks are only willing to take security interests in hard assets such as real estate and equipment. ${ }^{198}$ Businesses that have already mortgaged their real property and equipment cannot obtain additional financing even though they have good business plans or promising deals with their customers. This occurs because banks are reluctant to lend against inventory and account receivables. ${ }^{199}$ For example, a representative of Saigon Commercial Bank (Sacombank), a large commercial bank in Vietnam, disclosed that the amount of loans not secured by real property accounts for only six percent of total loans advanced by his bank. ${ }^{200}$ Banks usually accept equipment only as supplemental collateral if the value of the primary collateral - real estate - is not sufficient to secure the entire loan. ${ }^{201}$ An inventory-based secured transaction is usually structured as a pledge in which the lender-controlled field warehouse holds a fixed amount of inventory or warehouse title documents are delivered to the lender. ${ }^{202}$ Revolving loans secured by inventory and account receivables are very rare, and banks lend against account receivables on a single-account basis rather than on multiple accounts, ${ }^{203}$ due to the incomplete rules governing after-acquired property and proceeds.

The lack of collateral classification into consumer goods, inventory, farm products, and equipment results in the absence of

198 INT'L FIN. CORP., Vietnam: Increasing Access to Credit through Collateral (Secured Transactions) Reform 14 (2007), available at http://www.ifc.org/wps/wcm /connect/f0a39d8047ad9c5b9213f6752622ff02/VN-FIAS-Secure-Transaction-

ENG.pdf?MOD=AJPERES [hereinafter $I F C$ Report] ( "[L]ending in Vietnam is biased toward real estate"). Real property is the most preferred collateral, which was accepted by $93 \%$ of banks, followed by machinery and equipment, chosen by more than $60 \%$ of banks. Id. "Inventory can only be used as collateral by way of possessory pledge under which fixed amounts of inventory are held by lender-controlled field warehouses," or when warehouse title documents can be delivered to lenders. Id.

199 Huyen Thu \& Thanh Lan, Can Co Che Dac Biet Cho Doanh Nghiep Nho Vay Von [There Needs to Be a Special Lending Mechanism for Simall Businesses], VNEXPRESS (Sept. 24, 2013), http://kinhdoanh.vnexpress.net/tin-tuc/ebank/nganhang/can-co-che-dac-biet-cho-doanh-nghiep-nho-vay-von-2884254.html.

200 Id.

201 IFC Report, supra note 198, at 14.

202 Id.

$203 \mathrm{Id}$. at 17. 
specific rules protecting consumer debtors and farmers, as well as rules stimulating consumer and agriculture financing. Neither the Civil Code nor the regulations specifically address secured transactions involving consumers and farmers. Failing to encourage financing for farmers and consumers in a primarily agricultural country with a large domestic market of 90 million consumers is an unacceptable gap of secured transactions law. Unsurprisingly, the consumer financing market in Vietnam is still very modest, accounting for only $3.2 \%$ of total country loan book and $7.8 \%$ of nominal GDP, which is "far below the figures of the peer countries," including Indonesia, Malaysia, and Thailand. ${ }^{204}$

\section{B. Missing Perfection Rules}

While attempting to enhance transparency of secured transactions by adopting the registration (filing) mechanism, the Civil Code drafters failed to recognize that notice of a security right can be achieved by different methods, depending on the secured party's choice and the type of collateral. The law provides that registration (filing) is the only method to make a secured transaction effective against third parties. ${ }^{205}$ No other methods of perfection, such as taking possession, control, notation on certificate of title, or automatic perfection, are available in the Civil Code. ${ }^{206}$ This significant gap also emanates from the distinction between security devices and the lack of detailed collateral classification. For example, a pledge, which is distinguished from other security devices by the delivery of the collateral to the secured party, is treated as a separate security device rather than a method to give notice and determine priority (i.e. to perfect security interests). ${ }^{207}$ Moreover, without an

204 STOX RESEARCH, Vietnam Consumer Finance Report 2012-Summary, available at http://stoxresearch.com/Reports/1 19-vietnam-consumer-finance-report2012, aspx (last visited Mar. 15, 2014).

205 See C. CIV, art. $323 \S 3$ (Viet.) ("Where secured transactions are registered under the provisions of law, such secured transactions shall be legally valid for a third party as from the time of registration."); see also Decree on Security Transactions art. 11 ("A security transaction shall be legally valid for a third party [] from the time it is registered.").

206 See C. Civ. art. $323 \$ 3$ (Viet.); cf. U.C.C. \$ 9-308 - 9-314 (2010) (setting forth different available methods to perfect a security interest: perfection by taking possession, perfection by filing, perfection by control, automatic perfection upon attachment, and perfection by notation on certificate of title).

207 See C. Civ. art. 326 (Viet.) (defining “pledge”). 
elaborate classification of collateral, lawmakers do not understand that different kinds of collateral demand different methods of perfection. Although registration is the most common method of perfection, it is not the optimal method with respect to certain types of modern property or transactions.

With regard to possession, the law provides that the secured party may actually possess the collateral or authorize a third party to possess the collateral. ${ }^{208}$ However, the law does not articulate the requirements for possession by a third party to be effective (such as authentication by the third party acknowledging that it holds possession of the collateral for the secured party's benefit). ${ }^{209}$

With respect to control, although the law provides some vague provisions addressing possession and control of savings account and valuable papers (such as instruments and securities), it does not clarify the effect of such possession or control on the effectiveness of the secured transaction against a third party. ${ }^{210}$

\section{Missing Priority Rules}

As a result of incomplete rules for property collateral and perfection, priority rules in Vietnam's secured transactions law are skeletal and incoherent. There is no separate set of rules governing priorities ${ }^{211}$ apart from one single article of the Civil Code entitled "Priority order of payment" providing the general rule "first in time to file." "212 Other priority rules are scattered and buried in various parts of the Civil Code or the regulations implementing the Civil Code..$^{213}$

The Civil Code provides that if the secured transactions are registered, priority is determined based on the order of

208 See Decree on Security Transactions art. 16.

209 See Decree on Security Transactions art. $17 \S 3$ (mentioning briefly the rights and duties of a third party holding the pledged property); cf. U.C.C. $\S 9-313$ (c) (2010) (establishing that collateral can be held in possession of a person other than the debtor when the third party authenticates a record acknowledging the possession for the benefit of the secured party).

210 See Decree on Security Transactions art. 19.

211 Cf. LeGISLATIVE GuidE, supra note 8, Recommendations 76-109 at 204-13 (providing "rules for determining the priority of a security right ... "); U.C.C. $\$ \$ 9-317$ -9-339 (2010) (constituting a thorough and elaborate set of rules for priority).

212 C. Civ. art. 325 (Viet).

213 See, e.g., id. at art. 720(2), Decree on Security Transactions art. $13 \S 2$. 
registration. ${ }^{214}$ The secured party in a registered transaction will have priority over the secured party in an unregistered transaction. ${ }^{215}$ If all secured transactions are unregistered, priority is determined based on the order of creation of such secured transactions. ${ }^{216}$ These provisions oversimplify the complex priority issue in secured transactions. By emphasizing only one method of perfection (registration) as the basis to determine priority, these rules ignore the status of the secured party who takes possession or has control of the collateral in relation to the secured party who registers. Priority is determined only based on the order of registration, regardless of whether the secured party takes possession or control of the collateral or not. ${ }^{217}$

The law also completely fails to address priority between a secured party and a lien creditor, ${ }^{218}$ such as a judgment lien creditor, ${ }^{219}$ a bankruptcy trustee, ${ }^{220}$ or a tax lienholder. ${ }^{221}$

214 C. Civ. art. $325 \S 1$ (Viet).

$215 \mathrm{Id}$. at art. $325 \S 2$.

216 Id. at art. $325 \S 3$.

217 See Circular 05, supra note 185, at art. 2 (stating that registration of secured transaction is conducted even when the secured party or a third party takes possession of the collateral). This rule goes against the common sense of possessory security interest, because it is absurd that even if a secured party has possession of the collateral, it still needs to register the secured transaction to assert priority. This requirement not only places burden on the secured party but also renders possession of collateral meaningless.

218 Ho Quang Huy, Che Dinh Bao Dam Thuc Hien Nghia Vu Dan Su Trong Bo Luat Dan Su Nam 2005 Va Mot So Van De Can Nghien Cuu, Hoan Thien [Presentation at the Conference of the Ministry of Justice of Vietnam: The Civil Code 2005's Provisions on Security Rights and the Need to Improve] (June 27, 2013).

219 In Vietnam, civil judgments are enforced through a system of Judgment Enforcement Agencies. After levying on the judgment debtor's property, the Judgment Enforcer must register notice of levy on property at the registration office for secured transactions. However, the law does not specify priority between a secured party and a judgment creditor where the secured transaction has been registered before the decision of levy on property is issued and also does not make clear whether a good faith secured party will prevail if the Judgment Enforcer does not provide notice after the decision of levy on property has been issued. See Luật Số: 26/2008/QH12 Thi hành án dân sự [Law No: 26/2008/QH12 On Enforcement of Civil Judgments] The National Assembly (Nov. 14, 2008) (Viet.) available at http://www.moj.gov.vn/vbpq/Lists/Vn\%20 bn\%20php\%20lut/View_Detail.aspx?ItemID=12330 (Viet.), http://www.moj.gov. $\mathrm{vn} / \mathrm{vbpq} / \mathrm{en} / \mathrm{List} / \mathrm{Vn} \% 20 \mathrm{bn} \% 20 \mathrm{php} \% 20 \mathrm{lut} / V i e w \_D e t a i l . a s p x ? I t e m I D=10508$ (En.).

220 Under current bankruptcy law, Vietnam does not have the concept of "bankruptcy trustee;" instead, the judge and the creditors appoint a group of bankruptcy estate administrators. Article 35 of the Bankruptcy Law (2004) provides that:

Where the judges issue decisions to open the liquidation procedures 
Another significant gap in priority rules is the incomplete treatment of purchase-money security interest ("PMSI"). The law does not embrace a definition of PMSI and fails to recognize the importance of PMSI in stimulating production, trade, and consumption. The law briefly touches on the rights of a seller on credit and a financial lessor by providing that such seller or lessor can have super-priority over other secured parties. ${ }^{222}$ This superpriority rule, however, has a very limited scope: it only covers non-consumer transactions, and it does not distinguish between a PMSI in equipment and PMSI in inventory. ${ }^{223}$

\begin{abstract}
for enterprises or cooperatives, the debts secured with properties mortgaged or pledged before the courts receive the applications for opening of bankruptcy procedures shall be prioritized with repayment by such properties; if the value of the mortgaged or pledged property is not enough for debt repayment, the outstanding debts shall be repaid in the course of liquidating the properties of the enterprises or cooperatives; if the value of the mortgaged or pledged properties is bigger than the debts, the difference shall be added to the value of the remaining properties of the enterprises or cooperatives.
\end{abstract}

LAW ON BANKRUPTCY art. 35 (2004) (Viet.). The Bankruptcy Law fails to address whether a secured party must have registered the secured transaction to obtain priority in a bankruptcy proceeding, and the legal consequence of the secured party not registering the secured transaction before the petition date. See id. The new Bankruptcy Law, which takes effect on Jan. 1, 2015, contains virtually similar provisions with respect to security collateral. See LAW ON BANKRUPTCY art. 53 (2014) (Viet.).

221 The law does not specify priority in distribution of the proceeds generated from foreclosure of collateral of an enterprise owing tax debts but merely provides a general principle: where the tax debtor's money or other property held by a third party is subject to secured transactions or a bankruptcy case, the collection from said money or property held by third party shall be conducted in accordance with the law. LAW ON TAX MANAGEMENT art. 100 (Viet.) (2006) If the tax debtor has no other assets, the levying agency may levy on the tax debtor's property currently subject to a pledge or mortgage, if the value of said property is higher than the secured obligation. Id. The levying agency shall notify the pledgee or mortgagee about the levy. See Thông Tư Số: 157/2007/TT-BTC của Bộ Tài chính hướng dẫn về cưỡng chế thi hành quyết định hành chinh thuế [Circular No. 157/2007/TT-BTC Guiding the Enforcement of Tax Administrative Decisions] Ministry of Finance (Dec. 24, 2007) (Viet.) available at http://www.customs.gov.vn/Lists/EnglishDocuments/ViewDetails.aspx?language=enUS\&ID $=969$.

222 See Decree on Security Transactions art. $13 \S 2$.

223 Id. To be entitled to super-priority, the seller or lessor must satisfy the following requirements: (1) the collateral is purchased on credit, or is leased for more than one year, including machinery, equipment or other movable property that are not covered by a certificate of title, (2) the debtor is a business entity or a sole proprietorship with a business registration, and (3) the sale or lease contract is registered at a proper secured transactions registration office within fifteen (15) days after the execution of such 
Priority rules addressing different kinds of buyers are also missing. The fundamental concept of "buyer in the ordinary course of business" does not exist. The law only implies that the buyer or transferee of inventory subject to a mortgage can take the inventory free of the mortgage if the mortgagor sells or trades the inventory in the course of its business. ${ }^{224}$ Priorities as between a secured party and other kinds of buyers are also absent.

Due to the lack of specific rules on collateral classification and perfection, the priority rules tailored to certain kinds of collateral (including fixtures, securities, deposit accounts, and letter-of-credit rights) are non-existent.

\section{Missing Remedies Rules}

Vietnam's secured transactions law on remedies is superficial, posing major challenges to the secured party in enforcing its security right. Only three general provisions of the Civil Code address foreclosure on pledged property, ${ }^{225}$ and these provisions also apply to foreclosure on mortgaged property. ${ }^{226}$ Remedies are mainly governed by the regulations implementing the Civil Code, but these regulations are also incomplete. ${ }^{227}$ There are no specific provisions addressing "self-help," "no breach of the peace" duty, "commercially reasonable" disposition standard, procedural requirements for strict foreclosure, conditions for the debtor to redeem the collateral, conditions for the secured party to claim for deficiency after disposition, and remedies for the debtor when the secured party violates the rules for enforcement of the security interest. ${ }^{228}$ With incomplete remedies rules, however, Vietnamese law creates a burdensome and ineffective mechanism for a secured party to foreclose on the collateral when a debtor defaults.

contract. Id. If the sale or lease contract is not registered, or is registered after the 15day period and after a pre-existing secured transaction is registered, the secured party who registered first will have priority over the seller or the lessor. Id.

224 Id. at art. $20 \S 3$.

225 See C. Crv. arts. 336-38 (Viet.).

226 See C. CIV. art. 355 (Viet.).

227 See, e.g., Decree on Security Transactions arts. 56-71, Joint Circular No. 16/2014/TTLT-BTP-BTNMT-NHNN Providing Guidance on Several Issues Regarding Foreclosure of Collateral (Ministry of Justice, Ministry of Natural Resources and Environment, and State Bank of Vietnam, June 6, 2014) (Viet.).

228 See supra Part I, pp. 10-11, for discussion of remedies rules under modern secured transactions law. 
Under Vietnamese law, when the debtor is in default, the secured party has several options to foreclose on the collateral: (1) sell the collateral; (2) accept the collateral in satisfaction of the debt; (3) receive payment from the account debtor, if the collateral is an account; or (4) other methods agreed to by the parties. ${ }^{229}$ The method of foreclosure is agreed upon by the debtor and the secured party, or by the debtor and all of the secured parties who have taken security interests in the same collateral prior to default; if there is no agreement, the collateral will be sold at auction and the proceeds will be distributed among the parties in accordance with the law. ${ }^{230}$ The law is silent on whether the secured party's rights upon default are cumulative, including the rights under both judicial and extra-judicial mechanisms.

Vietnamese law does not allow a secured party to exercise selfhelp to repossess the collateral, which causes enormous challenges for the secured party. Before repossessing the collateral, the secured party has to give notice and request to the debtor or the party who is in possession of the collateral to turn over the collateral. ${ }^{231}$ The notice will set a grace period for the party in possession to deliver the collateral. ${ }^{232}$ If the party in possession fails to do so after the grace period expires, the secured party has the right to repossess the collateral to foreclose or bring a lawsuit. ${ }^{233}$ If the secured party chooses not to bring a lawsuit and instead repossesses the collateral, it must again give notice of repossession in a reasonable time before the repossession takes place. ${ }^{234}$ The notice must state the reason to repossess, time to repossess, and rights and duties of the parties in repossession. ${ }^{235}$ The burdensome requirements for notice of repossession enable the debtor to hide the collateral or otherwise hinder the secured party from repossessing.

The secured party has no right to unilaterally repossess the collateral without "breach of the peace." 236 The law requires that

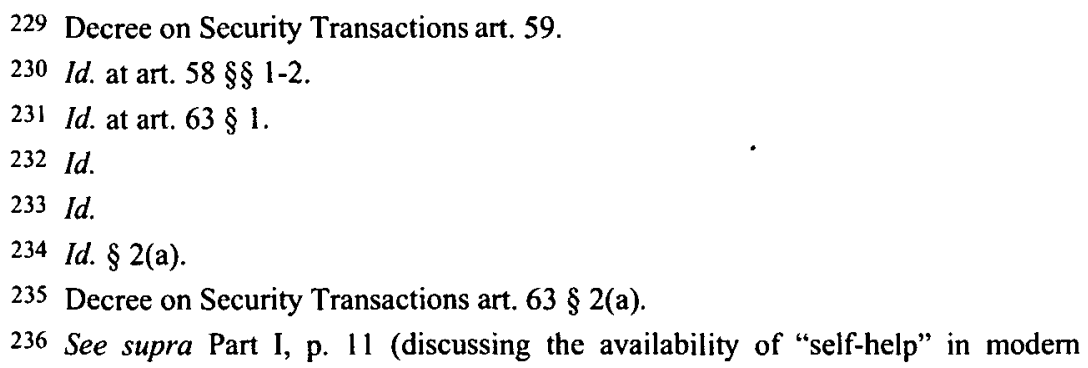


the repossession must occur with the debtor's presence. ${ }^{237}$ If the party in possession opposes or impedes the repossession, violates public security, or otherwise violates the law, the secured party can request the local authority and local police to maintain public order and facilitate the repossession. ${ }^{238}$ In reality, the debtor always tries to delay the delivery of the collateral or prevent secured parties from repossessing the collateral. ${ }^{239}$ In many cases, the secured party has to send numerous requests to turn over the collateral to the debtor and may even need to request the police department or local authorities to assist in repossession, ${ }^{240}$ which is very burdensome and may subject the repossession to the media's attention, creating unwanted publicity.

Due to the lack of an effective self-help mechanism, the secured party usually has to seek a judicial judgment allowing it to repossess and sell the collateral. ${ }^{241}$ Therefore, disputes concerning enforcement of a security interest, repossession, and foreclosure on the collateral are very common. In fact, they account for approximately $50 \%$ of total commercial cases handled by Vietnamese courts. ${ }^{242}$ Although this kind of dispute is usually not complicated, the secured parties must bring a lawsuit to obtain a judgment so that they can seek the judgment enforcement agency's support in seizure and disposition of the collateral. ${ }^{243}$ Despite the

secured transactions law).

237 Decree on Security Transactions art. $63 \S 2(\mathrm{~b})$.

238 Id. $\S 5$.

239 Ho Quang Huy, supra note 218.

240 See, e.g., Vietnam Thinh Vuong Joint Stock Commercial Bank v. Cuong Long Exp.-Imp. Trading Joint Stock Co., Judgment No. 147/2012/KDTM-ST (Hanoi People's Ct. Sept. 27, 2012) (Viet.) In this case, the bank lent 2 billion VND (100,000 USD) to the debtor to purchase a car valued at 3.7 billion VND and the car itself served as collateral to secure the debt. Id . at 6 . When the debtor defaulted, the bank sent multiple requests to turn over the collateral to the debtor, but the debtor refused to deliver the collateral to the bank. Id. The bank then filed a complaint to the Investigation Bureau of Hanoi Police Department, requesting the Bureau to repossess the car. Id. The Investigation Bureau took action to repossess the car as requested and delivered the car to the bank. Id.

241 Ho Quang Huy, supra note 218.

242 See Song Nguyen, An Tin Dung: Vuong Lat Vat Nhung Kho Go [Loan Dispute Cases: Minor Issues but Hard to Tackle], Phap Luat Thanh PHO Ho CHI Minh (Feb. 16, 2011), http://plo.vn/tap-chi-phap-luat/an-tin-dung-vuong-lat-vat-nhung-kho-go145505.html. In 2010, disputes involving secured lending transactions and financial leases handled by the Ho Chi Minh City People's Court reached 2,980 cases, constituting $50 \%$ of total commercial cases accepted by this court. Id.

243 See Interview with Ho Quang Huy, Deputy Director, National Registration 
straightforward nature of these disputes, the judicial process is often burdensome, costly, and lengthy. In many cases, the collateral disappears before a secured party can obtain a judgment to repossess and dispose of the collateral. ${ }^{244}$ Foreclosure through the court system may take two years, assuming that the judgment enforcement and sale of the collateral go smoothly. ${ }^{245}$ Even with a valid court judgment, nothing can guarantee that a secured party can successfully foreclose on the collateral due to the tremendous difficulties in enforcing a judgment. ${ }^{246}$

The absence of self-help, though often justified by lawmakers to prevent chaos, does not, in reality, ensure orderly repossession and foreclosure. Businesses are always in need of an efficient extra-judicial mechanism to quickly foreclose on the collateral and collect debts. The law, while failing to meet this need, opens the door to unlawful, unregulated self-help and violent practice of repossession and debt collection. A recent survey by the Vietnam Chamber of Commerce and Industry reveals that there is an increasing use of "unofficial forces" Vietnam. ${ }^{248}$ The judicial avenue costs a creditor an average of 400 days and $20-30 \%$ of the value of the debt, and carries a success rate of only $50-60 \%$. In contrast, collecting a debt via unlawful means costs a creditor an average of $15-30$ days, requires $40-70 \%$ of the value of the debt, and yields a higher success rate of 80 $90 \%{ }^{249}$

Apart from the non-existence of self-help, Vietnam's secured transactions law lacks many other rules governing remedies. For example, the law requires the secured party to give notice of foreclosure to other secured parties when the debtor is in default ${ }^{250}$

Agency for Secured Transactions, in Hanoi (Viet.) (June 14, 2012).

244 Ho Quang Huy, supra note 218.

245 Id.

246 See 7 Banks Attempt to Seize Goods from Debtor, supra note 15. This chaotic scenario could have been avoided if there were effective rules governing self-help and foreclosure in secured transactions law.

${ }^{247}$ Thu Hang, Thue "Xa Hoi Den" De Doi No: Xu Huong Dang Lo Ngai [Hiring "Gangs" to Collect Debts: A Worrying Trend], Phap Luat Thanh Pho Ho ChI MiNH (Mar. 10, 2014), available at http://plo.vn/thoi-su/thue-xa-hoi-den-doi-no-xu-huongdang-lo-ngai-453008.html.

248 Id.

249 Id.

250 The foreclosing secured party may (1) send notice of foreclosure to other secured 
but does not clarify the consequences of failure to provide notice. The law also does not make clear whether the secured party must give notice of disposition to the debtor or whether failure to give such notice will affect the right to claim for deficiency. Therefore, in practice, debtors frequently refuse to pay the deficiency after disposition of the collateral by contending that they did not receive proper notice of disposition. ${ }^{251}$

Moreover, because the law does not provide the "commercially reasonable" standard, a secured party has to go through a long appraisal process to determine the sale price, and this process depends significantly on the debtor's cooperation. ${ }^{252}$ The secured party and the debtor frequently dispute over the fair price of the collateral, prolonging the foreclosure process. For example, in one case, it took a financial lessor five years to have its deficiency claim resolved because the lessee disputed the value of the collateral. ${ }^{253}$ The lessee rejected the deficiency claim, contending that at the time of repossession, the lessor and lessee already examined the property and agreed on the value of the property, and that the lessee was not given notice of the sale and did not have a chance to participate in the sale. ${ }^{254}$ The trial court accepted the lessee's argument on the agreed value of the collateral and rejected the lessor's deficiency claim, which the appellate court affirmed. ${ }^{255}$ The appellate decision was reviewed by the Supreme People's

parties, or (2) register the notice of foreclosure at the secured transactions registration office. Decree on Security Transactions art. $61 \S 1$. The notice requirement must be fulfilled at least seven days before the foreclosure, if the collateral is personal property, or at least fifteen days before the foreclosure, if the collateral is real property, except in circumstances where the secured party can foreclose immediately as mentioned above. Id. at art. 62.

251 This method is especially common in financial lease disputes. See, e.g., Judgment No. 304/2013/KDTM-ST (Ho Chi Minh City People's Ct. Mar. 25, 2013) (Viet.) (discussing how the debtor contended that the secured party failed to give proper notice of the auction of the collateral); see also, e.g., Judgment No. 13/2012/KDTM-PT (Hanoi App. Div. of the Sup. People's Ct., Feb. 8, 2012) (Viet.); see also, e.g., Judgment No. 2109/2011/KDTM-ST (Ho Chi Minh City People's Ct., Dec. 6. 2011) (Viet.) The lessor refused to pay the deficiency because it did not receive notice of disposition of the leased property and because the sale price was lower than fair market value. Id.

252 See, e.g., Judgment No. 57/2012/KDTM-PT (Hanoi App. Div. of the Sup. People's Ct., Apr. 5, 2012) (Viet.).

253 See id.

254 Id. at 3.

255 Id. at 3-4. 
Court and was vacated and remanded to the appellate court. ${ }^{256}$ The second appellate panel held that although the parties initially agreed on the value of the leased property, they eventually disputed the sale price, because during the three month period after this agreement was reached, the lessor sent many letters to the lessee notifying that the agreed price was too high compared to fair market value, and asked the lessee to adjust the sale price, but the lessee declined. ${ }^{257}$ The court also noted that the lessor subsequently consulted the appraisal center under the Ministry of Finance to value the leased property and sold the property at fair market value based on this appraisal. ${ }^{258}$ Therefore, the court held that the lessor properly disposed of the collateral and could claim deficiency. ${ }^{259}$ In sum, the lessor had to wait for five years, from 2007 to 2012 , to obtain the final judgment. ${ }^{260}$ As a consequence of ineffective and incomplete remedies rules, financial leasing has been considerably decreasing in recent years. ${ }^{261}$

The law on foreclosure also fails to provide rules for determining damages when the secured party violates its duties after default, such as a duty to give notice of disposition or a duty to dispose of the collateral in a commercially reasonable manner. Disputes over the secured party's violation of the notice requirement and its right to claim deficiencies are very common, ${ }^{262}$

$256 I d$. at 5.

257 Id. at 6.

258 See Judgment No. 57/2012/KDTM-PT.

259 Id. at 7.

260 See generally Judgment No. 57/2012/KDTM-PT (Hanoi App. Div. of the Sup. People's Ct. Apr. 5, 2012) (Viet.) The complaint was filed in 2007, but it was not until 2012 that the final decision was rendered by the second appellate panel. Id.

261 Interview with Ho Quang Huy, supra note 243. This decrease is indicated in the significant decrease in the number of financial lease contracts registered at the secured transactions registration offices. The number of registrations of financial leases and sales with retention of title dropped from 3,528 in 2007 to 3,408 in 2008, 2,974 in 2009, 2,441 in 2010, and 1,149 in 2011. Nat'l. Registration Agency for Secured Transactions, (unpublished data) (2012) (Viet).

262 See, e.g., Judgment No. 304/2013/KDTM-ST (Ho Chi Minh City People's Ct., Mar. 25, 2013) (Viet.) The debtor contended that the secured party sold the collateral on auction without giving notice to the debtor. Id. See also, e.g., Judgment No. 13/2012/KDTM-PT (Hanoi App. Div. of the Sup. People's Ct., Feb. 8, 2012) (Viet.) The financial lessee argued that it did not receive notice of the sale and could not participate in the sale process. Id. See also, e.g., Judgment No. 2109/2011/KDTM-ST (Ho Chi Minh City People's Ct., Dec. 6, 2011) (Viet.) The financial lessee refused to pay the deficiency because it did not receive notice of disposition of the leased property and 
and the Civil Code does not provide specific rules to resolve these disputes.

The incomplete secured transactions law with respect to property collateral, perfection, priority, and remedies clearly hinders secured financing, because it fails to encourage the use of all kinds of property rights and assets as collateral and does not warrant certainty and adequate remedies for the secured party.

\section{Solutions For Transplanting Secured Transactions Law}

\section{A. Quick Fix with Additional Pain: The Decree Attempts}

Vietnam has engaged in a pattern of fixing shortcomings of Codes promulgated by the National Assembly. After the promulgation of the Civil Code in 1995, the Vietnamese government or "Chinh Phu" realized that the scope of the then secured transactions law was too narrow and passed Decree 165/1999/ND-CP [hereinafter Decree 165] to expand the scope. ${ }^{263}$ Prior to Decree 165, the secured transactions law did not allow non-possessory secured transactions. ${ }^{264}$ That meant only transactions where the creditor must either take possession of the collateral or have possession of certificates of title in the collateral were recognized. Consequently, financing transactions involving inventory and equipment were excluded from the legal framework. Individuals and entities were not permitted to leverage their rights in these types of property to obtain credit. Decree 165 was passed to allow some secured transactions for non-possessory security interest in inventory. ${ }^{265}$ Due to internal conflicts and rigid belief in the absolute separation between all things civil and all things commercial, Decree 165 was quickly undermined by the creation

because the sale price was lower than fair market value. Id.

263 See Decree on Security Transactions, Decree No. 165/1999/ND-CP (1999) (Viet.).

264 See Claude Rohwer, Progress and Problems in Vietnam's Development of Commercial Law, 15 BERKELEY J. INT'L L. 275, 285-86 (1997) (discussing the restrictive approach of the 1995 Civil Code to secured transactions before Decree 165 was promulgated).

265 See generally Decree on Security Transactions, No. 165. Decree 165, however, was undermined by the passing of a different decree, Decree No. 178/1999/ND-CP. See Decree on Credit Institutions Loan Security, No. 178/1999/ND-CP (1999) (Viet.). 
of Decree 178/1999/ND-CP in a matter of months. ${ }^{266}$

Likewise, after the Civil Code was amended in 2005, the Vietnamese Government passed Decree 163/2006/ND-CP [hereinafter Decree 163] to incorporate some features of modern secured transactions. ${ }^{267}$ Decree 163, however, cannot fix the roots of the secured transactions law problems, because the vastness of the problems is beyond its capability ${ }^{268}$ Moreover, using Decrees to fix secured transactions law buried deep inside the Civil Code has many shortcomings. These Decrees do not address the burdens and cost caused by an antiquated system of multiple security devices. ${ }^{269}$ These Decrees often conflict or contradict provisions in the Civil Code. ${ }^{270}$ These Decrees are unable to fill the gaps exposed by the incomplete secured transactions law. ${ }^{271}$ These gaps, such as lack of perfection, priority and remedies rules, are simply too large for the Decrees to address. Most importantly, these Decrees fail to recognize that new rights and interests based on property are being created daily. Consequently, these Decrees do not allow for a secured financing system that leverages new types of property effectively.

B. Different Placement Within the Civil Code? Moving from "Civil Obligations and Civil Contracts" to "Property Ownership" Section of the Civil Code

Another potential solution to address the secured transactions law problem is to move some of the articles of secured transactions law from the "Civil Obligations" Part to the "Property Ownership" Part of the Civil Code. ${ }^{272}$ Unfortunately, this solution is also laden with concerns.

First, this part is still buried deep inside the Civil Code.

266 See Decree on Credit Institutions Loan Security.

267 See Decree on Security Transactions, No. 163. Decree 163 also replaced Decree 165 and Decree 178.

268 See supra Part IV.

269 See supra Part III.A.

270 See supra Part III.B.

271 See supra Part IV.

272 This proposed solution is currently under consideration in Vietnam. See National Registration AgENCY For SECUREd TRANSActions of Vietnam ("NRAST"), Preliminary Draft of the Amendments to the Provisions on Security Devices of the 2005 Civil Code (Mar. 10, 2014) (unpublished). 
Revision cannot be made, as it must wait for the entire Civil Code to be revised. Outdated articles imposing restrictions and burdens on credit availability cannot be promptly revised to adapt to new market demands.

Second, fragmenting a body of secured transactions law by placing some articles under "Property Ownership" and other articles under "Civil Obligations and Civil Contracts" will cause confusion to debtors, creditors, and third parties. No one would know where to look for applicable laws and which laws would apply.

Last, and most importantly, separating secured transactions laws into two different Parts of the Civil Code would mean the secured transactions law is not necessary to increasing credit availability for a growing economy. It would mean that the drafters have no understanding of modern secured transactions law in the twenty-first century. Secured transactions are property and contract; therefore, the drafters should not place some articles under the "Property Ownership" part of the Civil Code and other articles under the "Civil Obligations and Civil Contracts" part of the Civil Code. The property used in secured transactions can be any right or interest in any type of property, such as stock, securities, intellectual property, promissory notes, chattel papers, letters of credit, bills of lading, air bills, accounts, licenses, inventory, equipment, farm products, consumer goods, and general intangibles. The property right or interest used as collateral for secured transactions purposes does not require ownership of the property, as any right or interest to the extent that the debtor has in particular collateral is sufficient. Contracts used in secured transactions are valid irrespective of form, either oral or written. They are agreements between the parties to create a security interest in identified collateral to secured obligation or performance. Secured transactions law facilitates and encourages the creation and enforcement of security interests in property rights and interests through the use of contracts.

On the other hand, continuing to keep secured transactions law under "Civil Obligations and Civil Contracts" does not reflect the true nature of secured transactions today. A separate body of law apart from the Civil Code is needed in order to fully address the credit needs of individuals and businesses. 


\section{A Separate Body of Law Apart from the Civil Code}

It is time for Vietnam to consider releasing secured transactions law from the "Civil Obligations and Civil Contracts" Part of the Civil Code. Adopting a separate body of law apart from the Civil Code will allow secured transactions law to grow and reflect the changes in a modern economy. ${ }^{273}$. These new transactions in daily commerce can be included in the scope of secured transactions. Revisions to secured transactions law can be made both promptly and deliberately in response to market changes without waiting for the entire body of the Civil Code to be revised.

Developing a separate body of law apart from the Civil Code is not without precedent in Vietnam. Vietnam has already done so with Intellectual Property Law. ${ }^{274}$ Due to market demands, Vietnam developed a separate body of intellectual property law and moved most of it outside the Civil Code. ${ }^{275}$ The result was an achievement that Vietnam was proud to present to its people and the world: a more complete and better developed intellectual property law that embraces most of the international intellectual

273 In particular, secured transaction law must be able to recognize new types of property rights and interests as collateral in secured financing

274 The Civil Code devotes a separate part to intellectual property rights and technology transfer. See C. Civ. part VI (Viet.). Historically, these provisions were necessary to set basic principles for intellectual property protection in Vietnam before the Law on Intellectual Property was enacted. See Christian Schaefer, Vietnam's Evolving Intellectual Property Law, 3 No. 4 ABA SCITECH LAW. 18 (2007) (stating that Part VI of the Civil Code provides the basic legal framework for intellectual property rights in Vietnam); see also EdWards FenNessy, 3 Trademarks Throughout the WORLD $\S$ 175:3 (noting that Part VI of the 1995 Civil Code "sets out the basic principles to be followed in new legislation on trademarks, industrial designs, patents, appellations of origin and copyrights.")

275 In 2005, the National Assembly passed the Law on Intellectual Property, which was the first comprehensive intellectual property legislation in Vietnam and retained only a few general provisions on intellectual property in the Civil Code (2005). Nevertheless, the Civil Code's provisions on intellectual property quickly became outdated and redundant after the Law on Intellectual Property and its guiding regulations were promulgated. See Ministry of Justice, ASSESSMENT OF THE IMPLEMENTATION OF THE CIVIL CODE, Report No. 151/BC-BTP at 15, 52 (July 15, 2013) (Viet.) (suggesting that the intellectual property provisions be taken out of the Civil Code because civil relations involving intellectual property and technology transfer have developed more complex and change so rapidly that the Civil Code's intellectual property provisions will soon become obsolete). 
property law and best practices. ${ }^{276}$

Vietnam can take the same approach with secured transactions law as it already did with intellectual property law. The drafters should draft a body of law that fully embraces modern secured transactions and international best practices, thereby increasing the credit available for Vietnam's growing economy. The new law should move away from the fragmented, multiple security devices approach and replace all devices with a unitary approach, as embodied in the UNCITRAL Legislative Guide and the United States Uniform Commercial Code Article 9. ${ }^{277}$

Via a thorough understanding of the purposes of modern secured transactions law, the drafters can ensure that each provision and article of secured transactions law be drafted to meet the purposes. For example, the new law should contemplate the reality of new types of property rights and interests that could be used as collateral in secured financing. That means the new law should be inclusive to all new collateral and have a system of identifying and classifying the collateral. Consequently, more individuals and businesses could use new types of property rights and interests as collateral in financing, and lenders could rely on these collateral property rights and interests for lending.

The new law should address the missing perfection, priority, and remedies rules. Without perfection, priority, or remedies, there is no transparency, and no orderly determination of who has rights in what collateral. Furthermore, there is no systematic disposition of said collateral and no systematic recourses for all parties in secured transactions. With a complete set of rules for perfection, priority, and remedies, the new law can truly encourage financing and enhance the availability of credit for individuals and businesses.

Vietnam, with a new separate body of secured transactions law apart from the Civil Code, would join other nations in Asia and throughout the world in modernizing its financing system. ${ }^{278}$

276 See LaW ON INTEllectual Property No. 50/2005/QHII (Viet.) (2005).

277 See LegiSlative GuidE, supra note 8, I 50, at 20; see also U.C.C. § 9-109(a) (2010) (indicating the scope of secured transactions law covers all kinds of secured transactions, regardless of forms).

278 See Gordon Walker \& Alma Pekmezovic, Legal Transplanting: International Financial Institutions and Secured Transactions Law Reform in South Pacific Island Nations, 25 N. Z. L. Rev. 560, 560 (2013). 
Vietnam would enable individuals and businesses to gain access to credit so that new businesses, new jobs, and new economic growth can occur, allowing Vietnam to fully integrate into the global economy and compete in the global market.

\section{Conclusion}

It is time for Vietnam and other emerging economy countries to truly encourage the availability of credit for individuals and businesses in order to create new jobs, manufacture new products, and expand commerce. Countries with developing economies must shed the vestiges of the Roman law approach and adopt a modern secured transactions law as embodied in UNCITRAL's Legislative Guide and international best practices. 